\title{
Down-regulation of MicroRNA-31 in CD4+ T Cells Contributes to Immunosuppression in Human Sepsis by Promoting $\mathrm{T}_{\mathrm{H}} 2$ Skewing
}

\author{
Verena van der Heide, M.D., Patrick Möhnle, M.D., Jessica Rink, B.S., Josef Briegel, M.D., \\ Simone Kreth, M.D., Ph.D.
}

\section{ABSTRACT}

Background: Immunosuppression has been recognized as a major cause of sepsis-related mortality. Currently, there is much interest in identifying central hubs controlling septic immunoparalysis. In this context, in this study, the authors investigate the role of microRNA-31 (miR-31) as a regulator of T cell functions.

Methods: Primary human T cells were separated from healthy volunteers $(\mathrm{n}=16)$ and from sepsis patients by magnetic beads $(\mathrm{n}=23)$. Expression of mRNA/microRNA (miRNA) was determined by real-time polymerase chain reaction. Gene silencing was performed by small interfering RNA transfection, and miRNA-binding sites were validated by reporter gene assays. Effects of miR-31 or anti-miR-31 transfection were analyzed by real-time polymerase chain reaction, Western blotting, and flow cytometry.

Results: Overexpression of miR-31 in stimulated $\mathrm{CD} 4^{+} \mathrm{T}$ cells promoted a proinflammatory phenotype with increased levels of interferon- $\gamma(1.63 \pm 0.43 ; P=0.001$; means $\pm \mathrm{SD})$ and reduced expression of interleukin (IL) $-2(0.66 \pm 0.19 ; P=0.005)$ and IL-4 $(0.80 \pm 0.2 ; P=0.0001)$. In contrast, transfection of anti-miR-31 directed cells toward a $\mathrm{T}_{\mathrm{H}} 2$ phenotype. Effects on IL-2 and IL-4 were mediated by targeting of nuclear factor-kappa B-inducing kinase and factor-inhibiting hypoxia-inducible factor- $1 \alpha$. Interferon- $\gamma$, however, was influenced via control of signaling lymphocytic activation molecule (SLAM)-associated protein, an essential adaptor molecule of immunomodulatory SLAM receptor signaling, which was identified as a novel target gene of miR-31. In sepsis patients, an epigenetically driven down-regulation of miR-31 was found $(0.44 \pm 0.25 ; P=0.0001)$, associated with increased nuclear factor-kappa B-inducing kinase, factor-inhibiting hypoxia-inducible factor-1 $\alpha$, SLAMassociated protein expression, and a cytokine shift toward $\mathrm{T}_{\mathrm{H}} 2$.

Conclusions: In this study, the authors provide novel evidence of miR-31 as an emerging key posttranscriptional regulator of sepsis-associated immunosuppression. The study results contribute to a further understanding of septic immunoparalysis and provide new perspectives on miRNA-based diagnostic approaches. (ANESTHesiologr 2016; 124:908-22)

$S^{n}$ EPSIS is a life-threatening systemic inflammatory disorder, resulting from a harmful host response to invading pathogens or their toxins. ${ }^{1,2}$ After the onset of sepsis, an initial hyperactivation of the innate immune system takes place that persists for a few days, followed by a more protracted period of deleterious immunosuppression, ${ }^{3}$ predominantly characterized by defective adaptive immune mechanisms, including increased suppressive potency of regulatory $\mathrm{T}$ cells $\left(\mathrm{T}_{\text {reg }}\right)^{4}$ and myeloid derived suppressor cells. ${ }^{5,6}$ Recent studies have shown that the majority of deaths in sepsis occur during this immunoparalytic state due to persistent infections and general exhaustion of the patients' organ systems. ${ }^{7,8}$

A growing body of evidence indicates that $\mathrm{T}$ cells play a pivotal role as mediators of sepsis-induced immunosuppression. Apoptotic T cell depletion, ${ }^{9,10} \mathrm{~T}$ cell exhaustion, which is characterized by a failure to produce cytokines and
What We Already Know about This Topic

- Accumulating evidence points to immunosuppression as a contributor to development and progression of sepsis.

\section{What This Article Tells Us That Is New}

- In 23 patients with sepsis, a microRNA termed miR-31 was down-regulated, and this was associated with increased antiinflammatory signaling and a shift in T-helper cells toward a predominance of $\mathrm{T}_{\mathrm{H}} 2$ (antiinflammatory) subtypes. This suggests that, in sepsis, decreased expression of miR-31 contributes to depression of immunity.

up-regulation of inhibitory surface proteins, ${ }^{11-14}$ and a shift from a predominantly proinflammatory $\mathrm{T}_{\mathrm{H}} 1$ to an antiinflammatory $\mathrm{T}_{\mathrm{H}} 2$ immune phenotype are the hallmarks of the aberrant adaptive immune responses in sepsis. ${ }^{15,16} \mathrm{How}-$ ever, the mechanisms driving these alterations still need to

Supplemental Digital Content is available for this article. Direct URL citations appear in the printed text and are available in both the HTML and PDF versions of this article. Links to the digital files are provided in the HTML text of this article on the Journal's Web site (www. anesthesiology.org).

Submitted for publication June 10, 2015. Accepted for publication December 16, 2015. From the Department of Anesthesiology, University of Munich Ludwig Maximilian University, Munich, Germany.

Copyright $\odot$ 2016, the American Society of Anesthesiologists, Inc. Wolters Kluwer Health, Inc. All Rights Reserved. Anesthesiology 2016; 124:908-22 
be unveiled, and identification of molecular checkpoints and key regulatory molecules is a nascent field in sepsis research.

MicroRNAs (miRNAs) are small noncoding RNAs, which posttranscriptionally repress expression of target genes by base paring to their $3^{\prime}$ untranslated region ( $3^{\prime}$ UTR). ${ }^{17}$ They are key participants in gene regulatory networks controlling virtually all cellular functions and play a crucial role in a plethora of diseases including cancer and inflammation. ${ }^{18-20}$ Recently, microRNA-31 (miR-31), a pleiotropically acting tumor suppressor miRNA, ${ }^{21,22}$ has been identified as a regulator of two strongly interrelated key transcription factor families, namely hypoxia-inducible factor (HIF)-1 $\alpha$ and nuclear factor-kappa B (NF- $\mathrm{B}$ ). MiR-31 activates the HIF pathway in human head and neck carcinoma by targeting factor-inhibiting HIF- $1 \alpha(\mathrm{FIH})^{23}$ and restricts the noncanonical NF- $\kappa \mathrm{B}$ pathway in adult $\mathrm{T}$ cell leukemia by repressing NF- $\mathrm{KB}$-inducing kinase (NIK). ${ }^{24}$

We assumed that miR-31 could be a molecular checkpoint of $\mathrm{T}$ cell functions because both HIF-1 $\alpha$ and members of the NF- $\kappa \mathrm{B}$ family of transcription factors have previously been identified as potent regulators of $\mathrm{T}$ cell-mediated immunity. Hypoxia, a prominent feature of most inflammatory processes, leads to stabilization of HIF-1 $\alpha$, which in turn promotes the induction of antiinflammatory mechanisms in human $\mathrm{T}$ cells. ${ }^{25-}$ 27 Likewise, members of the NF- $\mathrm{KB}$ family are activated in response to inflammatory stimuli, relying on the canonical pathway through activation of the inhibitor of kappa B kinase complex or the noncanonical pathway via NIK, both resulting in the transcription of proinflammatory and antiapoptotic genes. ${ }^{28,29}$

In the current study, we show that miR-31, indeed, affects $\mathrm{T}$ cell functions. We demonstrate that transfection of miR-31 influences the balance of $\mathrm{T}_{\mathrm{H}} 1 / \mathrm{T}_{\mathrm{H}} 2$ cytokine transcription by favoring a $\mathrm{T}_{\mathrm{H}} 1$ bias. This is accomplished by targeting FIH and NIK as well as by regulation of a newly identified miR-31 target gene, SH2D1A, encoding the intracellular adaptor molecule signaling lymphocytic activation molecule (SLAM)-associated protein (SAP). We further demonstrate that an activation-induced repression of miR-31 occurs in $\mathrm{T}$ cells of sepsis patients, which promotes a shift from $\mathrm{T}_{\mathrm{H}} 1$ to $\mathrm{T}_{\mathrm{H}} 2$ cytokine transcription and thus contributing to the development of sepsis-induced immunosuppression.

\section{Materials and Methods}

\section{Sepsis Patients and Healthy Controls}

Blood samples were obtained between May 2009 and April 2012 from 23 sepsis patients (table 1) within $48 \mathrm{~h}$ after clinical diagnosis according to the criteria of the American College of Chest Physicians/Society of Critical Care Medicine consensus conference. ${ }^{30}$ Blood withdrawal was repeated after a time span of $24 \mathrm{~h}$ in case of seven enrolled patients who were diagnosed with early-stage sepsis (symptoms onset less than $4 \mathrm{~h}$ ). Exclusion criteria were patients younger than $18 \mathrm{yr}$, prior antibiotic or corticosteroid treatment, immunodeficiency, and malignant diseases. Samples from 16 healthy volunteers who had been recruited between May 2009 and April 2012 in the context of the current and of two previously published studies $^{31,32}$ were included as matched controls (table 1 ). All studies involving human subjects were approved by the Institutional Review Boards of the Ludwig Maximilian University of Munich, Munich, Germany (No. 107-11) and the University Hospital of Jena, Jena, Germany (No. 2007-004333-42, local amendment for Munich University Hospital 2242-03/08). Written informed consent was received from all subjects or legal substitutes.

\section{Purification of T Cells from Human Peripheral Blood}

Peripheral blood mononuclear cells were isolated from EDTA blood $(30 \mathrm{ml})$ by density gradient centrifugation (Histopaque 1077; Sigma-Aldrich, Germany), and $\mathrm{CD}^{+}$or $\mathrm{CD}^{+} \mathrm{T}$ cells

Table 1. Characteristics of Sepsis Patients and Healthy Controls

\begin{tabular}{lcc}
\hline & Sepsis Patients & Healthy Controls \\
\hline Number & 23 & 16 \\
Gender (female/male) & $9 / 14(39.1 \% / 60.9 \%)$ & $6 / 10(37.5 \% / 62.5 \%)$ \\
Age, yr (mean \pm SD) & $55.9 \pm 18.0$ \\
Positive blood culture & $15(65.2 \%)$ \\
Source of sepsis & \\
$\quad$ Pneumonia & $8(34.8 \%)$ \\
$\quad$ Urinary tract infection & $3(13.0 \%)$ \\
Intraabdominal infection & $1(4.4 \%)$ \\
$\quad$ Central nervous system infection & $6(26.1 \%)$ \\
$\quad$ Other & $5(21.7 \%)$ \\
Septic shock & $9(39.1 \%)$ \\
Interleukin-6 median (range), pg/ml & $869(30.8-59,434)$ \\
C-reactive protein median (range), mg/dl & $15.5(0.5-343.2)$ \\
Leukocyte median (range), / $\mu \mathrm{l}$ & $13.2 \times 10^{3}\left(2.4-37.8 \times 10^{3}\right)$ \\
Sequential organ failure score $(\mathrm{mean} \pm \mathrm{SD})$ & $11.0 \pm 5.1$ \\
Nonsurvivors & $7(30.4 \%)$
\end{tabular}

Healthy controls were nonsmoking individuals without history of acute or chronic infection, immunosuppressive diseases, or cancer. 
were subsequently enriched by negative selection using the Pan T cell isolation kit II or the $\mathrm{CD}^{+} \mathrm{T}$ cell isolation kit (Miltenyi Biotec, Germany), respectively. Cell number and viability were assessed by a ViCell analyzer (Beckman Coulter, Germany). Purity of separated $\mathrm{CD}^{+}$and $\mathrm{CD}^{+}{ }^{+} \mathrm{T}$ cells was determined by flow cytometry on an Attune Acoustic Focusing Cytometer (Life Technologies, Germany) and was more than $96 \%$ on average (Supplemental Digital Content 1, fig. S1, http://links.lww.com/ALN/B247).

\section{Cell Culture}

Human Embryonic Kidney-293 cells (ECACC, United Kingdom) were grown in Dulbecco's Modified Eagle's Medium (Lonza, Switzerland), supplemented with 10\% heat-inactivated Fetal Calf Serum (Biochrom, Germany), 1\% non-essential amino acids (Biochrom), and $1 \%$ penicillin/streptomycin $/ \mathrm{L}$ glutamine (Life Technologies). Primary T cells from healthy controls were cultured in Roswell Park Memorial Institute (RPMI)-1640 (Sigma-Aldrich) supplied with 10\% heat-inactivated Fetal Calf Serum, 1\% HEPES (Sigma-Aldrich), and $1 \%$ penicillin/streptomycin/L-glutamine (Life Technologies) at $37^{\circ} \mathrm{C}$ and $5 \% \mathrm{CO}_{2}$. For hypoxic conditions, cell cultures were maintained under a gas mixture of $3 \% \mathrm{O}_{2}$ and $5 \% \mathrm{CO}_{2}$ in an air-tight hypoxia chamber (Billups-Rothenberg, USA), which was then placed into a tissue culture incubator.

\section{T Cell Stimulation Conditions}

Purified $\mathrm{CD}^{+} \mathrm{T}$ cells from healthy controls were activated in 24-well plates $\left(1 \times 10^{6}\right.$ in $1 \mathrm{ml}$ of complete RPMI) with antiCD3/CD28 Dynabeads (Life Technologies) according to the manufacturer's recommendations and harvested at the indicated time points. Enriched human $\mathrm{CD} 4^{+} \mathrm{T}$ cells were stimulated for the given periods of time in 12 -well plates $\left(1.5 \times 10^{6}\right.$ in $1.5 \mathrm{ml}$ of complete RPMI) with anti-CD3/CD28 Dynabeads or in 96-well plates $\left(0.2 \times 10^{6}\right.$ in $0.2 \mathrm{ml}$ of complete RPMI) using plate-bound anti-CD3 $(5 \mu \mathrm{g} / \mathrm{ml}$; clone OKT3) and soluble antiCD28 (5 $\mu \mathrm{g} / \mathrm{ml}$; clone CD28.2; both from BioLegend, USA).

\section{Vector Constructs}

The psiCHECK-2 vector (Promega, Germany) was used for creating SH2D1A 3'-UTR reporter constructs. In brief, the SH2D1A 3'-UTR was polymerase chain reaction (PCR) amplified from human genomic DNA (50 ng), using the following cycling conditions and the primers listed in table S1 (Supplemental Digital Content 1, http://links.lww.com/ ALN/B247) (Metabion, Germany): denaturation at $95^{\circ} \mathrm{C}$ for $5 \mathrm{~min}, 35$ cycles of $95^{\circ} \mathrm{C}$ for $30 \mathrm{~s}, 64.6^{\circ} \mathrm{C}$ for $30 \mathrm{~s}, 72^{\circ} \mathrm{C}$ for $90 \mathrm{~s}$, and a final elongation at $72^{\circ} \mathrm{C}$ for $5 \mathrm{~min}$. The PCR product was ligated into the $\mathrm{pSC}-\mathrm{B}$ amp/kan vector using the StrataClone Ultra Blunt PCR cloning kit (Stratagene, USA) and, subsequently, cloned downstream the Renilla luc reporter gene into the Xhol/PmeI restriction sites of the psiCHECK-2 vector. Next, the two predicted hsa-miR-31-5p-binding sites in the SH2D1A 3'-UTR (TargetScan Version 4.233) were sequentially eliminated using the QuikChange lightning site-directed mutagenesis kit (Stratagene) according to the manufacturer's protocol. All reporter constructs were verified by sequence analysis (Eurofins MWG Operon, Germany).

\section{Transient Transfection of Primary Human T Cells}

Transient transfection of miRNA mimics and small interfering RNAs (siRNA) into $\mathrm{CD}^{+}{ }^{+} \mathrm{T}$ cells was performed by electroporation with the Neon Transfection System (Life Technologies). In brief, $\mathrm{CD}^{+} \mathrm{T}$ cells from healthy controls were transfected with $50 \mathrm{nM}$ Ambion pre-miR-31-5p or scrambled control (both from Life Technologies), rested in complete RPMI-1640 without antibiotics for $6 \mathrm{~h}$ and, subsequently, stimulated in 12-well plates $\left(1.5 \times 10^{6}\right.$ in $1.5 \mathrm{ml}$ of RPMI) with anti-CD3/ CD28 Dynabeads for 24h. Gene silencing experiments were performed accordingly for up to $48 \mathrm{~h}$ with specific siRNAs directed against SH2D1A, FIH (both $50 \mathrm{nM}$ ), and NIK $(100 \mathrm{nM})$ or with scrambled control (all ON-TARGETplus SMARTpool from GE Dharmacon, USA). For in vitro inhibition of hsa-miR-31-5p, purified $\mathrm{CD}^{+} \mathrm{T}$ cells of healthy donors were incubated in 96-well plates $\left(0.2 \times 10^{6}\right.$ in $0.1 \mathrm{ml}$ of Accell delivery medium) with $1 \mu \mathrm{M}$ of Accell miRNA inhibitor of hsa-miR-31-5p or scrambled control (GE Dharmacon) as per manufacturer's recommendation and left untreated or stimulated with anti-CD3/CD28 Dynabeads at a bead-to-cell ratio of 1:1 for $72 \mathrm{~h}$. Successful transfection was determined by flow cytometry in case of (anti-)miRs, using Cy3-labeled pre-miR negative control (Life Technologies) and DY-547-labeled Accell miRNA inhibitor nontargeting control (GE Dharmacon) or by quantitative polymerase chain reaction (qPCR) verification of target knockdown in case of siRNA transfection.

\section{Luciferase Assay}

Human Embryonic Kidney-293 cells were cotransfected by electroporation with the various SH2D1A 3'-UTR reporter plasmids $(1 \mu \mathrm{g})$ containing the putative/mutated miR-31$5 \mathrm{p}$-binding sites as well as $50 \mathrm{nM}$ pre-miR-31-5p or scrambled control and incubated in 12 -well plates $\left(0.15 \times 10^{6}\right.$ in $1 \mathrm{ml}$ of complete Dulbecco's Modified Eagle's Medium without antibiotics) for $48 \mathrm{~h}$. Subsequently, firefly and renilla luciferase activities were quantified on a MicroLumat Plus instrument (Berthold Technologies, Germany) using the Dual Glo Luciferase Assay System (Promega).

\section{RNA Extraction and complementary DNA Synthesis}

Total RNA was extracted from purified $\mathrm{CD}^{+} \mathrm{T}$ cells or transiently transfected $\mathrm{CD}^{+} \mathrm{T}$ cells using the miRVana miRNA isolation kit, the RNAqueous total RNA isolation kit or the RNAqueous-Micro total RNA isolation kit, respectively (all from Life Technologies), followed by DNAse-digest with the Turbo-DNA free kit (Life Technologies). Quantity and purity of the isolated RNA were determined using a NanoDrop 2000 spectrophotometer (Thermo Scientific, USA). complementary DNA was synthesized from 500 ng up to $1 \mu \mathrm{g}$ of total RNA using the SuperScript III First Strand Synthesis System (Life Technologies). 


\section{Quantitative Real-time PCR (qPCR)}

All analyses were performed in duplicates on a Light Cycler 480 instrument (Roche Diagnostics, Germany) as described in the study by Ledderose $e t$ al. $^{31}$ In brief, quantification of mRNA expression was performed using Universal Probe Library probes (Roche Diagnostics), specifically designed primers (Probe Finder Software; Roche Diagnostics; primers synthesized by Metabion; see Supplemental Digital Content 1, table S2, http://links.lww.com/ALN/B247) and the following cycling conditions: initial denaturation at $95^{\circ} \mathrm{C}$ for $5 \mathrm{~min}, 45$ cycles at $95^{\circ} \mathrm{C}$ for $10 \mathrm{~s}, 60^{\circ} \mathrm{C}$ for $30 \mathrm{~s}$, and $72^{\circ} \mathrm{C}$ for $15 \mathrm{~s}$. Succinate dehydrogenase subunit A and TATA Box Binding Protein were used as reference genes in all experiments $^{34}$ and relative mRNA expression was calculated with the Light Cycler Relative quantification software (Roche Diagnostics). To assess miR-31 expression, equal amounts of extracted total RNA ( $2 \mathrm{ng}$ ) were reversely transcribed using the TaqMan Micro RNA reverse transcription kit (Life Technologies). Endogenous miR-31 expression was subsequently determined by qPCR with U47 RNA as internal control, using a specific TaqMan Micro RNA Assay (Life Technologies) and applying the following cycling conditions: denaturation at $95^{\circ} \mathrm{C}$ for $10 \mathrm{~min}, 45$ cycles of $95^{\circ} \mathrm{C}$ for $15 \mathrm{~s}$, and $60^{\circ} \mathrm{C}$ for $60 \mathrm{~s}$.

\section{Intracellular Staining and Flow Cytometry}

For intracellular staining of SH2D1A, stimulated $\mathrm{CD}^{+} \mathrm{T}$ cells $\left(0.2-0.5 \times 10^{6}\right)$ of healthy donors were harvested at the indicated time points, washed twice with Hank balanced salt solution containing $1 \%$ bovine serum albumin and $0.01 \%$ sodium azide (both from Sigma-Aldrich) and stained for surface expression of CD4 (PerCP-conjugated anti-human CD4, clone RPA-T4; BioLegend) and CD25 (fluorescein isothiocyanate-conjugated anti-human CD25, clone BC96; BioLegend). Next, cells were fixed and permeabilized using the FoxP3/Transcription Factor Staining Buffer Set according to the manufacturer's instructions (eBioscience, USA) and stained for intracellular expression of SH2D1A (phycoerythrin-conjugated anti-human SAP, clone XLP-1D12; eBioscience). All analyses were performed on an Attune Acoustic Focusing Cytometer (Life Technologies) by sequential gating on lymphocytes, measuring 20,000 to 30,000 events per tube (Supplemental Digital Content 1, fig. S2, http://links. lww.com/ALN/B247). Unstained, unstimulated, and isotype controls (from BioLegend and eBioscience) were used as gating controls.

\section{Western Blot}

For the preparation of whole cell extracts, primary $\mathrm{CD}^{+}$ and $\mathrm{CD}^{+} \mathrm{T}$ cells of healthy controls were harvested, washed with ice-cold phosphate buffered saline and resuspended in $150 \mu \mathrm{l}$ of $1 \mathrm{x}$ cell lysis buffer plus $1 \mathrm{x}$ protease/phosphatase inhibitor cocktail (all from Cell Signaling, USA). Nuclear cell extracts were prepared using the nuclear extract kit (Active Motif, Belgium) according to the manufacturer's instructions. Subsequently, cell lysates were vortexed, sonified, and incubated on ice for $30 \mathrm{~min}$. Total protein extracts were collected after centrifugation $\left(10 \mathrm{~min}, 15,000 \mathrm{~g}, 4^{\circ} \mathrm{C}\right)$, and protein concentration was determined by bicinchoninic acid assay (Thermo Scientific). Cell extracts (up to $15 \mu \mathrm{g}$ protein) were separated on 8,10 , or $14 \%$ sodium dodecyl sulfate-polyacrylamide gel electrophoresis and blotted on polyvinylidene difluoride membranes. NIK and FIH proteins were detected using rabbit polyclonal (NIK) or monoclonal (FIH, clone D19B3) antibodies, and SH2D1A was detected using rabbit polyclonal or rat monoclonal (clone XLP-1D12) antibodies (all antibodies from Cell Signaling). $\beta$-Actin (mouse monoclonal antibody, clone 8H10D10) or Lamin A (polyclonal antibody) were used as endogenous standards. Immunoreactive bands were subsequently detected using horseradish-labeled goat anti-mouse, goat anti-rabbit, or goat anti-rat antibodies (Cell Signaling). Image J (NIH; available at: http://rsbweb.nih.gov/ij/) was used for quantification of all Western blot bands.

\section{Bioinformatics and Statistical Analyses}

MicroRNA-31 target genes were identified on the basis of a stringent microRNA support vector regression score cutoff of -1.0 or lower ${ }^{35}$ by using the prediction programs TargetScan, Probability of Interaction by Target Accessibility, and miRanda. ${ }^{33,36,37}$ Estimation of sample sizes was based on previous experience in the field of miRNA analysis. Generally, at least three independent experiments (i.e., $\mathrm{n} \geq 3$ ) were performed, and, with the exception of Western blot and flow cytometry analyses, all measurements were done in duplicates (qPCR) or triplicates (transfection assays). Data were tested for normal distribution by using the KolmogorovSmirnov and Shapiro-Wilk tests. Differences between groups were analyzed by using paired or unpaired Student's $t$ test (two tailed) in case of parametric distribution and twotailed Mann-Whitney U or Wilcoxon signed-rank test for nonparametric distribution. One-way ANOVA with Tukey multiple comparisons test was used to compare more than two groups. Pearson correlation coefficient (two-tailed test) was used to measure linear correlation in case of parametric distribution, whereas Spearman correlation coefficient (twotailed test) was used to determine measure linear correlation in case of nonparametric distribution. Statistical significance was defined as a $P$ value of less than $0.05\left({ }^{*} P<0.05\right.$; $\left.{ }^{* *} P<0.001\right)$. If not stated otherwise, values given represent means \pm SD. GraphPad Prism 6 software (GraphPad Software, Inc., USA) was used for all analyses.

\section{Results}

\section{T Cell Activation Leads to miR-31 Down-regulation}

To explore the biological role of miR-31 in human T cells, we first assessed the expression kinetics of mature miR-31 in human $\mathrm{CD}^{+} \mathrm{T}$ cells obtained from healthy volunteers after $\mathrm{T}$ cell receptor (TCR)-specific activation. As shown in figure $1 \mathrm{~A}$, abundance of miR-31 remained largely unchanged 

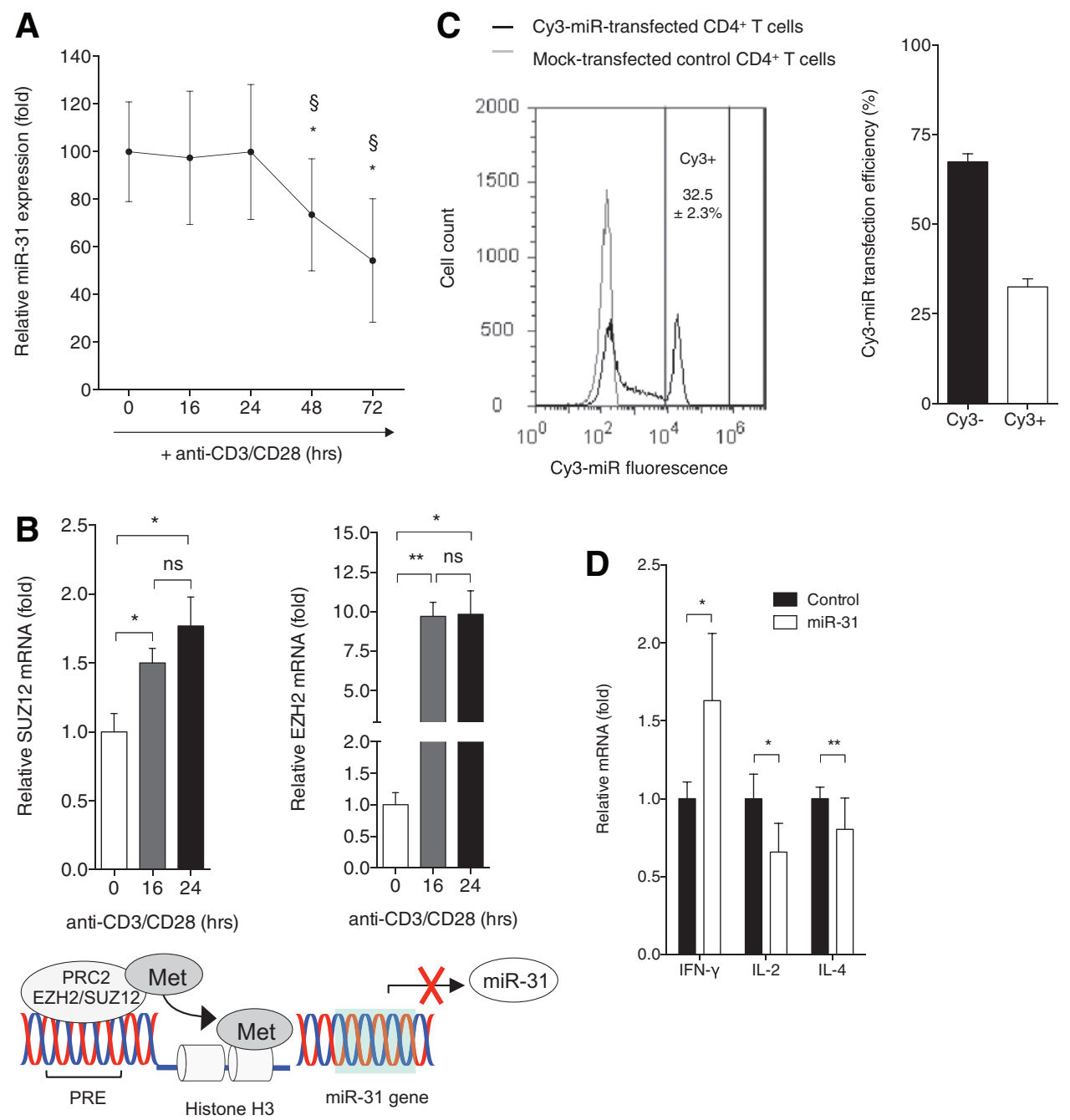

Chr $9 p 21.3$

Fig. 1. MicroRNA-31 (miR-31) is down-regulated in stimulated human Tcells and impairs the balance of $\mathrm{T}_{\mathrm{H}} 1 / \mathrm{T}_{\mathrm{H}} 2$ cytokine transcription. (A) $\mathrm{CD}^{+}$T cells were purified from peripheral blood of healthy donors $(n=4)$ and were left untreated or activated with anti-CD3/CD28 Dynabeadsfor 16,24,48, and72 h, respectively. Relativeexpressionofmaturehsa-miR-31-5pwasquantified byquantitativepolymerase chain reaction (qPCR) with U47 RNA as endogenous control. Data are means $\pm \mathrm{SD} ;{ }^{*} P=0.038$, 48 versus $0 \mathrm{~h}$, and $P=0.036,72$ versus $0 \mathrm{~h}$; $\S P=0.0395,48$ versus $16 \mathrm{~h}$, and $P=0.0168,72$ versus $16 \mathrm{~h}$, in one-way ANOVA with Tukey post test. (B) Left panel presents relative SUZ12 and EZH2 mRNA levels at the indicated time points, as determined by qPCR in stimulated human T cells from $A$. Data are means \pm SD; SUZ12: not significant (ns) $P=0.2954,16$ versus $24 \mathrm{~h},{ }^{\star} P=0.0107,24$ versus $0 \mathrm{~h}$, and $P=0.0352,16$ versus $0 \mathrm{~h}$ as well as EZH2: ns $P=0.9811,16$ versus $24 \mathrm{~h},{ }^{*} P=0.0022,24$ versus $0 \mathrm{~h}$, and ${ }^{* \star} P=0.0008,16$ versus $0 \mathrm{~h}$ in one-way ANOVA with Tukey post test. Right panel depicts epigenetic regulation of miR-31 by polycomb repressive complex 2 (PRC2), consisting of the catalytic subunit EZH2 and three noncatalytic subunits SUZ12, RBAP48, and embryonic ectoderm development (latter two not shown). This complex is recruited to a genomic region (PRC response element [PRE]) upstream the miR-31 locus on chromosome 9 (Chr 9p21.3), leading to miR-31 repression via chromatin silencing through histone $\mathrm{H} 3$ methylation (Met). (C, D) CD4+ $\mathrm{T}$ cells from healthy donors were transiently transfected with Cy3-labeled pre-miR scrambled control, Ambion pre-miR-31-5p, or pre-miR scrambled control, respectively, and stimulated for $24 \mathrm{~h}$ with anti-CD3/CD28 Dynabeads. (C) Transfection efficiency was determined by flow cytometry as the percentage of Cy3-fluorescent cell number in total cell number. Left panel shows representative histogram, and right panel indicates calculated total transfection efficiency (open bar) of $n=3$ individual experiments performed in triplicates. Data are means \pm SD. (D) Total RNA was isolated from stimulated CD4 ${ }^{+} \mathrm{T}$ cells transiently transfected with Ambion pre-miR-31-5p or scrambled control. Relative interferon (IFN)- $\gamma$, interleukin (IL)-2, and IL-4 mRNA expression was measured by quantitative real-time PCR. Data represent means \pm SD of $\mathrm{n}=5$ healthy donors. IFN- $\gamma:{ }^{\star} P=0.001, \mathrm{IL}-2:{ }^{\star} P=0.005$, and IL-4: ${ }^{\star \star} P=0.0001$ in paired Student's $t$ test.

during the first $24 \mathrm{~h}$ after stimulation. Thereafter, a constant decline occurred resulting in a reduction of miR-31 expression by almost $50 \%$ after $72 \mathrm{~h}(54.3 \pm 25.9 ; P=0.0036$; fig. 1A). To gain insight into the underlying mechanisms, we measured the mRNA expression of SUZ12 and EZH2, which have recently been shown to epigenetically repress the 
A

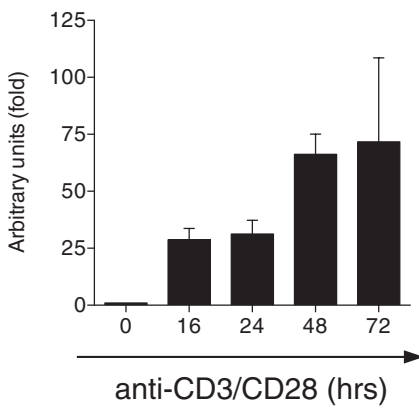

NIK

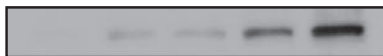

$(125 \mathrm{kDa})$

$\beta$-Actin

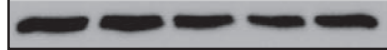

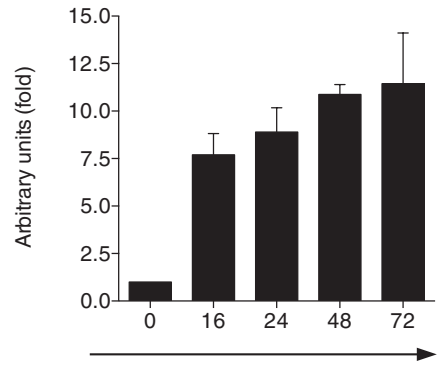

anti-CD3/CD28 (hrs)

$\mathrm{FIH}$

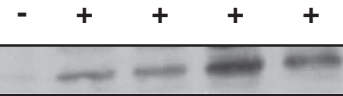

(42 kDa)

$\beta$-Actin
(40 kDa)

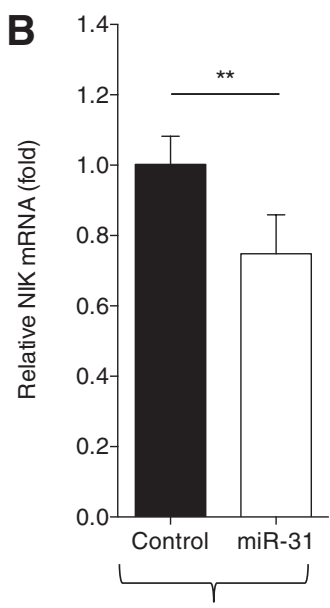

+ 24 hrs anti-CD3/CD28

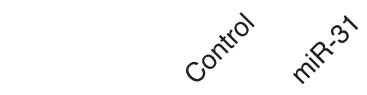

NIK $(125 \mathrm{kDa})$

$\beta$-Actin (40 kDa)

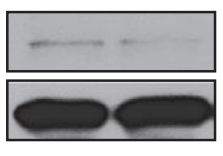

+24 hrs anti-CD3/CD28
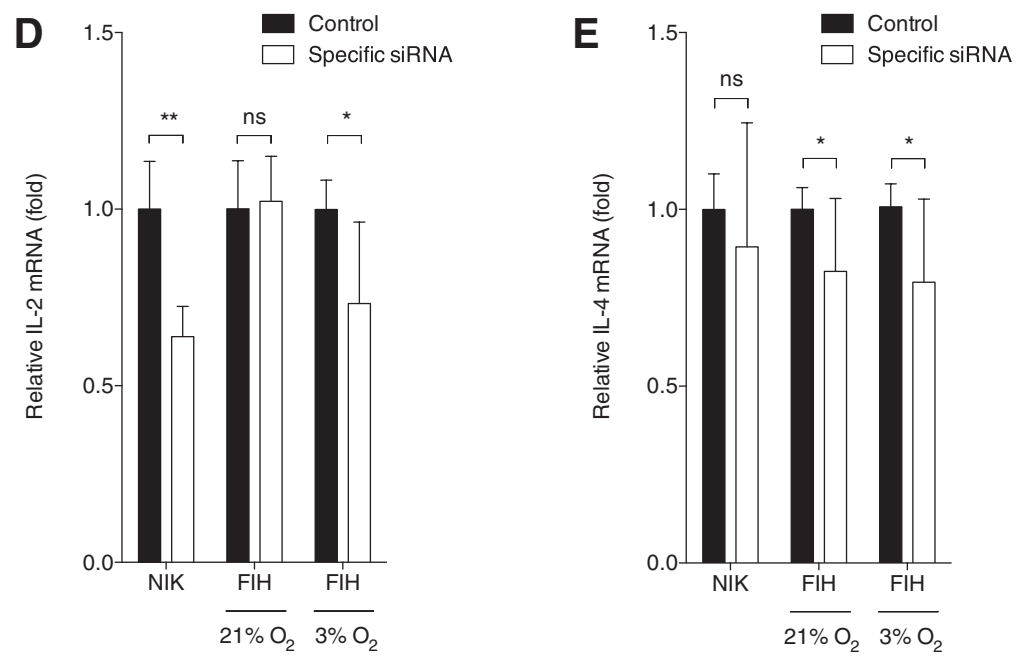
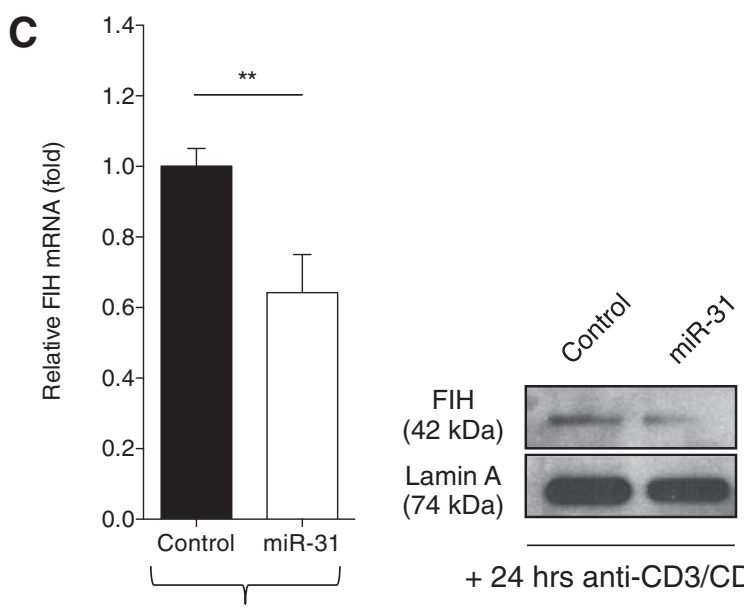

+24 hrs anti-CD3/CD28

+ 24 hrs anti-CD3/CD28

Fig. 2. MicroRNA-31 (miR-31) regulates $\mathrm{T}_{H}$ cytokine transcription via targeting nuclear factor-kappa B-inducing kinase (NIK) and factor-inhibiting hypoxia-inducible factor- $1 \alpha(F I H)$. $(A) C D 3^{+}$T cells from healthy donors $(n=3)$ were stimulated with anti-CD3/ CD28 Dynabeads and harvested at the indicated time points. Controls (labeled "-") were left untreated (no anti-CD3/CD28 Dynabeads). Kinetics of NIK (left panel) and FIH (right panel) protein abundance were determined by Western blot analysis. One blot is representative of $n=3$. Graphs above indicate fold induction (arbitrary units, normalized to $\beta$-actin-loading control) in relation to protein expression before stimulation. Data are means \pm SEM. $(B, C) C D 4^{+} T$ cells of healthy donors $(n=5)$ were transiently transfected with Ambion pre-miR-31-5p (miR-31) or pre-miR scrambled control (control), rested for $6 \mathrm{~h}$ and, subsequently, stimulated with anti-CD3/CD28 Dynabeads for $24 \mathrm{~h}$. Relative NIK (B, left panel) and FIH mRNA (C, left panel) as well as protein expression 
expression of miR-31. ${ }^{24,38}$ Concordantly, both transcripts sharply increased during the first $24 \mathrm{~h}$ after $\mathrm{T}$ cell stimulation (SUZ12: $P=0.0107$; EZH2: $P=0.0022$; fig. $1 \mathrm{~B})$. Collectively, these data show an inverse relationship between $\mathrm{T}$ cell activation and endogenous miR-31 expression and strongly suggest functional relevance of this miR in human $\mathrm{T}$ cells.

\section{Overexpression of miR-31 Impairs the Balance of $T_{H} 1 / T_{H} 2$ Cytokine Transcription}

To study the functions of miR-31 in primary human $\mathrm{T}$ cells, we transfected miR-31 mimic into $\mathrm{CD}^{+} \mathrm{T}$ cells of healthy donors and quantified gene transcription of the key $T$ helper $\left(\mathrm{T}_{\mathrm{H}}\right)$ cytokines interleukin (IL)-2, IL-4, and interferon (IFN) $-\gamma$ in response to $T$ cell stimulation. Transfection efficiencies were determined by flow cytometry in relation to mock-transfected $\mathrm{CD}^{+} \mathrm{T}$ cells of respective donors $(32.53 \pm 2.26 \%$; fig. 1C). Overexpression of miR-31 reduced IL-2 and IL-4 mRNA levels by almost $35 \%$ (IL-2: $0.66 \pm 0.19$; $P=0.005)$ and $20 \%$ (IL-4: $0.80 \pm 0.2 ; P=0.0001$ ), respectively, whereas IFN- $\gamma$ mRNA copies were markedly up-regulated $(1.63 \pm 0.43 ; P=0.001$; fig. $1 D)$. Prompted by these results pointing to a central role of miR-31 in T cell-mediated immunity, we next aimed to identify those miR-31 target genes accountable for the observed effects.

\section{miR-31 Regulates $T_{H}$ Cytokine Transcription via Targeting NIK and Factor-inhibiting HIF-1 $\alpha$}

In tumor cells, NIK/MAP3K14 and FIH/HIF1AN have previously been identified as miR-31 targets. ${ }^{23,24}$ Whether this functional relationship also exists in human $\mathrm{T}$ cells has not been investigated so far.

Assuming that-in case of regulation-activationinduced decrease of miR-31 would result in higher protein expression of these direct miR-31 targets, we performed Western blot analyses on stimulated $\mathrm{CD}^{+} \mathrm{T}$ cell lysates of healthy donors. As shown in figure 2A, a 75 -fold greater abundance of NIK (left panel) and a 10-fold greater

Fig. 2. (Continued). ( $B$ and $C$, right pane/s) was detected by quantitative polymerase chain reaction (qPCR) and Western blot analysis, respectively. Data are presented as means \pm SD. NIK: ${ }^{* *} P=0.0003$ and $F I H$ ${ }^{\star}{ }^{\star} P<0.0001$ in paired Student's $t$ test. One blot representative of $n=3$ is shown. $(D-F) C D 4^{+}$T cells, enriched from peripheral blood mononuclear cells of healthy donors ( $n=3$ to 7 ), were transiently transfected with specific small interfering RNAs (siRNAs) against NIK and FIH (open bars) or scrambled control and stimulated for up to $48 \mathrm{~h}$ under normoxic $\left(21 \% \mathrm{O}_{2}\right)$ or hypoxic conditions $\left(3 \% \mathrm{O}_{2}\right)$. Relative gene transcription of $T_{H} 1 / T_{H} 2$ cytokines interleukin (IL)-2 (D), IL-4 $(E)$, and interferon (IFN)- $\gamma(F)$ was quantified by qPCR. Data are means \pm SD. IL-2: NIK ${ }^{* *} P=0.0001$, FIH $\left(21 \% \mathrm{O}_{2}\right)$ not significant (ns) $P=0.6357$, FIH $\left(3 \% \mathrm{O}_{2}\right)$ ${ }^{*} P=0.0020 ; \quad I L-4:$ NIK ns $P=0.2981$, FIH $\left(\begin{array}{ll}21 \% & \mathrm{O}_{2}\end{array}\right)$ ${ }^{*} P=0.0239$, FIH $\left(3 \% \mathrm{O}_{2}\right){ }^{*} P=0.0116 ;$ IFN $-\gamma:$ NIK ns $P=0.9253$, FIH $\left(21 \% \mathrm{O}_{2}\right){ }^{\star *} P<0.0001, \mathrm{FIH}(3 \%$ O2) ${ }^{\star \star} P=0.0005$ in paired Student's $t$ test. abundance of FIH (right panel) was detectable in T cells activated for 3 days compared with untreated controls. To further confirm the hypothesis that NIK and FIH expression in human $\mathrm{T}$ cells is negatively regulated by miR-31, we analyzed mRNA and protein levels of both target genes after transfection of miR-31 mimic into $\mathrm{CD}^{+}{ }^{+} \mathrm{T}$ cells of healthy donors. As shown in figure 2, B and C, overexpression of miR-31 led to substantial suppression of NIK and FIH transcripts (NIK: $0.75 \pm 0.11, P=0.0003$; FIH: $0.64 \pm 0.11$; $P<0.0001$; left panels) as well as of the corresponding proteins (right panels).

Since both the NF-KB and HIF- $1 \alpha$ pathways are involved in the orchestration of $\mathrm{T}$ cell responses,${ }^{27}$ we next investigated whether the observed effects of miR-31 on $\mathrm{T}_{\mathrm{H}}$ cytokine production are, at least partially, mediated by NIK and FIH. To this end, we performed siRNA-mediated knockdown experiments of either NIK or FIH in $\mathrm{CD}^{+}$lymphocytes of healthy donors and quantified the mRNA expression of IL-2, IL-4, and IFN- $\gamma$. To rule out the possibility that FIHmediated effects were potentially dampened by proteasomal degradation of HIF- $1 \alpha$ in normoxia $\left(21 \% \mathrm{O}_{2}\right)$, these experiments were additionally performed under moderate hypoxic conditions $\left(3 \% \mathrm{O}_{2}\right)$, thereby mimicking reduced oxygen tensions routinely encountered in lymphoid tissues. ${ }^{39,40}$ Specific knockdown of both target genes affected the expression of IL-2 mRNA similarly to miR-31: NIK silencing induced a repression of $36 \%(0.64 \pm 0.09 ; P=0.0001)$, whereas $\mathrm{FIH}$ silencing under hypoxic conditions led to a $27 \%$ reduction $(0.73 \pm 0.23 ; P=0.0020$; fig. $2 \mathrm{D})$, thus supporting our hypothesis. Moreover, IL- 4 transcripts decreased as a result of FIH knockdown both under normoxic and hypoxic conditions $\left(21 \% \mathrm{O}_{2}: 0.82 \pm 0.21 ; P=0.0239 ; 3 \% \mathrm{O}_{2}: 0.79 \pm 0.24\right.$; $P<0.05$; fig. 2E). Surprisingly, effects of miR-31 on IFN- $\gamma$ mRNA expression could be mimicked by silencing of neither NIK nor FIH, respectively. Contrary to the previously observed up-regulation, IFN- $\gamma$ mRNA expression was not influenced by silencing of NIK, whereas FIH knockdown led to reduced IFN- $\gamma$ transcripts both under normoxic and hypoxic conditions (fig. 2F).

Conclusively, these findings suggest that miR-31 exerts its effects on IL-2 and IL-4 mRNA expression of human CD4 ${ }^{+}$ cells by targeting NIK and FIH. However, both target genes were not accountable for the effects on IFN- $\gamma$ transcription observed upon transfection of miR-31.

\section{SH2D1A Is a Novel miR-31 Target and Modulates IFN- $\gamma$ Expression in Human CD4+ $\mathrm{T}$ Cells}

To find the missing link between miR-31 and IFN- $\gamma$ mRNA expression, we used in silico analyses, which predicted SH2D1A as a promising candidate gene bearing two putative miR-31-binding sites with favorable prediction scores in its 3'-UTR (fig. 3A). SH2D1A encodes SAP, an intracellular adaptor molecule involved in $\mathrm{T}$ cell-mediated immunity. Because targeted mutation in the SH2D1A gene in murine $T$ cells has been shown to result in enhanced IFN- $\gamma$ 
A

NM_002351.4

NM_001114937.2

ATG (start)

STOP

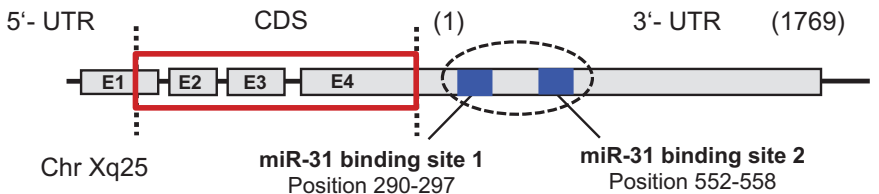

5، ...AGGAUUAAUGUCAAUUCUUGCC... 5، ...UUCUGAAAGCAACCUUCUUGCC.. I I II I I I

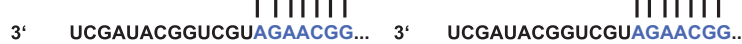

B
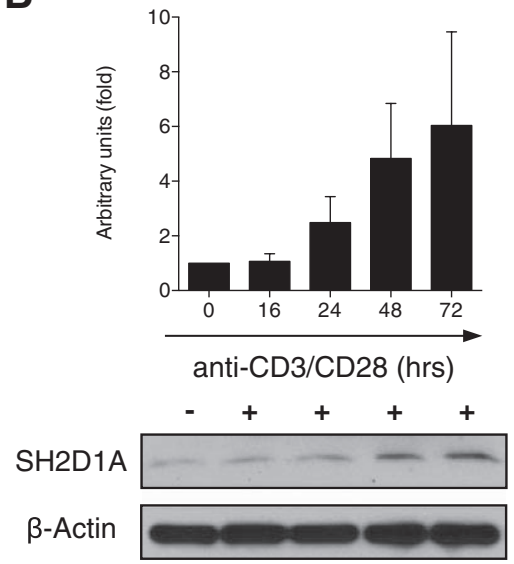

$14 \mathrm{kDa})$

$(40 \mathrm{kDa})$
C
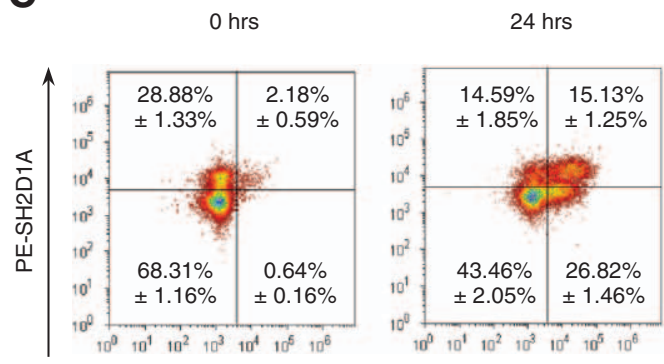

48 hrs

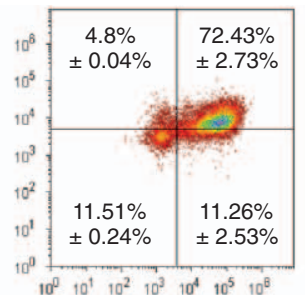

$72 \mathrm{hrs}$

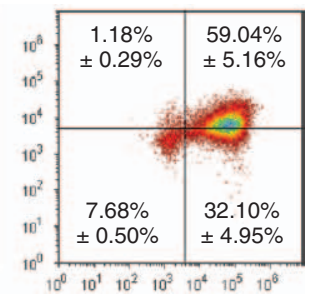

$10^{0} \quad 10^{1} \quad 10^{2} \quad 10^{3} \quad 10^{4} 10^{5} \quad 10^{6}$

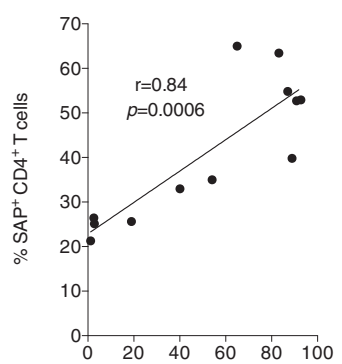

$\%$ of CD25 $5^{+}$cells
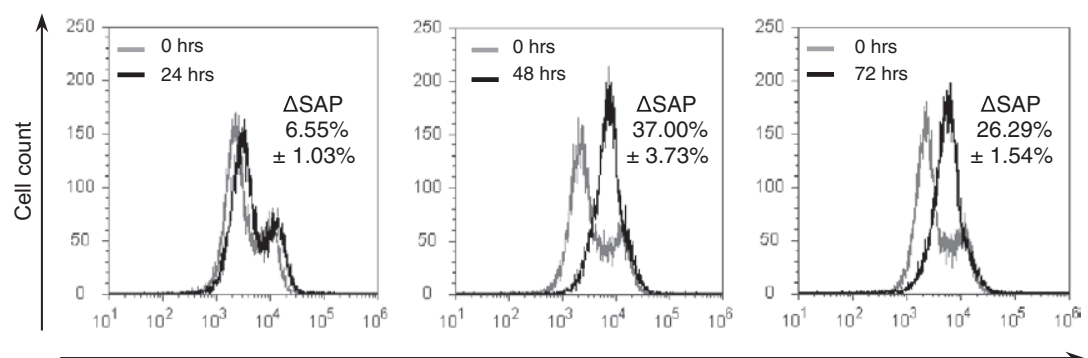

PE-SH2D1A

D

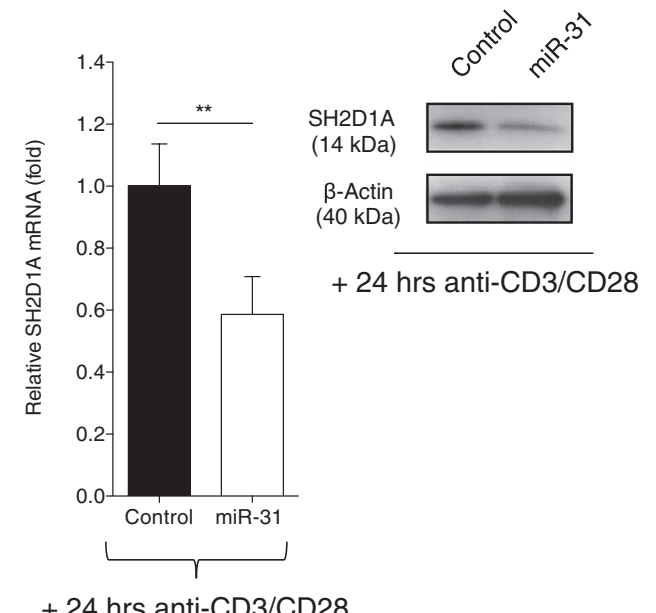

E

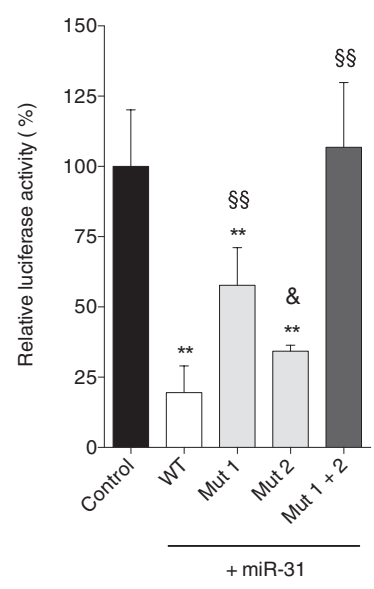

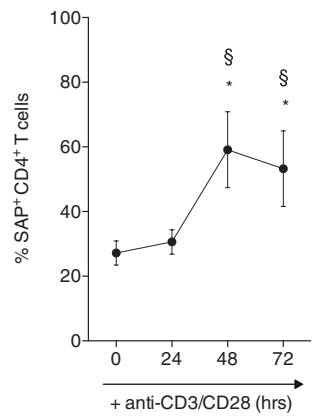

$\mathbf{F}$

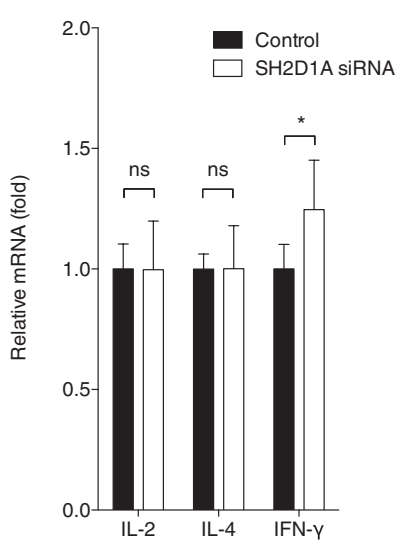

Fig. 3. SH2D1A is a novel microRNA-31 (miR-31) target and modulates interferon (IFN)- $\gamma$ expression in human CD4+ T cells. (A) Depiction of the genomic structure of the human SH2D1A gene on chromosome $\mathrm{X}$ and location of putative 
Fig. 3. (Continued). miR-31-5p-binding sites in its $3^{\prime}-$ untranslated region ( $3^{\prime}$-UTR). The SH2D1A gene comprises four exons (E1-E4); the coding sequence (CDS) is marked by a red box, ending with a 1769-nt UTR. Target prediction algorithms identified two putative miR-31-binding sites, indicated by bold blue lines with positions and seed sequences given below. $(B)$ Kinetics of SH2D1A/signaling lymphocytic activation molecule-associated protein (SAP) protein expression were evaluated by Western blot analysis in anti-CD3/CD28 stimulated CD3 ${ }^{+} \mathrm{T}$ cells of healthy donors $(n=3)$. One representative blot is shown; the graph above denotes fold induction (arbitrary units, normalized to $\beta$-actin-loading control) in relation to protein expression before stimulation. Data are means \pm SEM. $(C)$ CD4 ${ }^{+} T$ cells from healthy donors $(n=3)$ were left untreated or stimulated with plate-bound anti-CD3 and soluble anti-CD28 for 24,48 , and $72 \mathrm{~h}$. Cells were analyzed for expression of surface CD25 as well as intracellular SAP by flow cytometry. Upper panel graph: correlation of SAP and CD25 expression; Pearson $r=0.84 ; P=0.0006$. Lower panel graph: kinetics of SAP expression in stimulated $\mathrm{CD} 4^{+} \mathrm{T}$ cells of all three donors. Data are means $\pm \mathrm{SD}$. ${ }^{\star} P=0.0064,48$ versus $0 \mathrm{~h}$, and $P=0.0066,72$ versus $0 \mathrm{~h}$, $\S P=0.0143,48$ versus $24 \mathrm{~h}$, and $P=0.0272,72$ versus $24 \mathrm{~h}$ in one-way ANOVA with Tukey post test. Representative plots and histograms of one donor are shown, with individual stains performed in duplicates. All plots are gated on "live" cells, as determined by forward/side scatter properties. Percentages are means \pm SD. Percentage increase of SAP in relation to unstimulated cells $(0 \mathrm{~h})$ denoted as $\triangle \mathrm{SAP}$ means $\pm \mathrm{SD}$. $(D) \mathrm{CD}^{+} \mathrm{T}$ cells of healthy donors $(n=5)$ were transiently transfected with Ambion pre-miR31-5p (miR-31) or pre-miR scrambled control (control) and, subsequently, stimulated with anti-CD3/CD28 Dynabeads for $24 \mathrm{~h}$. Relative SH2D1A mRNA (left panel) as well as protein (right panel) expression was measured by quantitative polymerase chain reaction and Western blot analysis. Data are presented as means \pm SD. ${ }^{* \star} P<0.0001$ in paired Student's $t$ test. One blot representative of $n=3$ is shown. $(E)$ The SH2D1A 3'-UTR containing the putative mir-31-binding sites was cloned into the psiCHECK-2 reporter vector. Control constructs lacking either one (Mut 1: binding site 1, Mut 2: binding site 2) or both (Mut 1 +2 ) of the miR-31-binding sites were generated by site-directed mutagenesis. Wild-type (WT) SH2D1A 3'-UTR (open bar) as well as mutant controls (shaded gray bars) were cotransfected with Ambion pre-miR-31-5p into Human Embryonic Kidney-293 cells, and hRLuc reporter activity was determined relative to WT SH2D1A 3'-UTR cotransfected with pre-miR-scrambled control (control, black bar). Data are expressed as means \pm SD of $n=9$ to 18 experiments. ${ }^{\star \star} P<0.0001$ : WT versus control, Mut 1 versus control, Mut 2 versus control; $\S \S P<0.0001$ Mut 1 versus WT, Mut $1+$ 2 versus WT; \&P $=0.0187$ Mut 2 versus Mut 1 in one-way ANOVA with Tukey post test. $(F)$ Relative mRNA expression of $T_{H} 1 / T_{H} 2$ cytokines interleukin (IL)-2, IL-4, and IFN- $\gamma$ was quantified in $\mathrm{CD} 4^{+} \mathrm{T}$ cells transiently transfected with specific small interfering RNA (siRNA) directed against SH2D1A (open bars) or with scrambled control and stimulated for $48 \mathrm{~h}$. Data are means $\pm \mathrm{SD}$ of $\mathrm{n}=6$ healthy donors. IL-2: not significant (ns) $P=0.9533$; IL-4: ns $P=0.9833$; IFN- $\gamma:{ }^{*} P=0.002$ versus control in paired Student's $t$ test. FITC $=$ fluorescein isothiocyanate. production, ${ }^{41,42}$ we hypothesized that the miR-31-induced up-regulation of IFN- $\gamma$ in human T cells might be accomplished by repression of SH2D1A.

Once again, we performed Western blot analyses on $\mathrm{CD}^{+}$ $\mathrm{T}$ cell extracts up to $72 \mathrm{~h}$ after stimulation with immobilized anti-CD3 and soluble anti-CD28 and found increasing SAP expression kinetics strongly resembling those of NIK and FIH (fig. 3B). Flow cytometric analyses of stimulated $\mathrm{CD}^{+} \mathrm{T}$ cells showed that SAP expression strongly correlated with CD25, a surface marker of enhanced T cell activation $(r=0.84 ; P=0.0006$; fig. 3C, see upper panel for representative dot plots). Although SAP was detected in only $30 \%$ of resting $\mathrm{CD}^{+} \mathrm{T}$ cells $(27.2 \pm 3.7 \%$; see graph in lower panel), $65 \%$ of $\mathrm{CD}^{+} \mathrm{T}$ cells exhibited intracellular SAP after 3 days of stimulation $(53.3 \pm 11.7 \% ; P=0.0066)$. In line with these results suggesting that $\mathrm{SH} 2 \mathrm{D} 1 \mathrm{~A}$ might also be a miR-31 target gene, transfection of miR-31 mimic into activated $\mathrm{CD}^{+}$ $\mathrm{T}$ cells of healthy donors resulted in substantially reduced SH2D1A mRNA $(0.59 \pm 0.13 ; P<0.0001$; fig. 3D, left panel) as well as protein levels (right panel).

To provide experimental proof that SH2D1A is a bona fide target of miR-31, we performed luciferase reporter gene assays on vector constructs containing the full-length SH2D1A 3'-UTR. As shown in figure 3E, cotransfection of miR-31 mimic and wild-type SH2D1A 3'-UTR diminished luciferase activity by $80 \%$ compared with miR scrambled control $(80.5 \pm 9.5 \% ; P=0.0001)$. Dinucleotide exchanges in both seed match sequences partially restored luciferase activity to $60 \%$ (Mut 1 [Mutation seed match 1]: $57.7 \pm 13.4 \%$; $P=0.0001$ ) and 35\% (Mut 2 [Mutation seed match 2]: $34.4 \pm 2.2 \% ; P=0.0001)$, respectively, whereas mutation of both binding sites completely abolished the observed miR-31 effect on reporter gene expression (Mut $1+2$ : $106.7 \pm 23 \% ; P=0.8298)$. Thus, our data prove that miR31 directly regulates $\mathrm{SH} 2 \mathrm{D} 1 \mathrm{~A}$ expression by binding to the identified target sites in its $3^{\prime}$-UTR.

Having demonstrated a functional relationship between miR-31 and SH2D1A, we next turned to the question whether miR-31 up-regulates IFN- $\gamma$ transcription via repression of SH2D1A. Therefore, we analyzed IFN- $\gamma$ transcripts in stimulated $\mathrm{CD}^{+} \mathrm{T}$ cells after transfection of siRNA directed against SH2D1A or scrambled control. In accordance with our hypothesis, qPCR demonstrated significantly increased IFN $-\gamma$ mRNA levels $(1.25 \pm 0.21$; $P=0.002$; fig. 3 F), whereas both IL-2 and IL-4 remained largely unaffected. Hence, our data indicate that miR-31 modulates IFN- $\gamma$ transcription in primary human $\mathrm{CD}^{+} \mathrm{T}$ cells through the newly identified target gene SH2D1A.

\section{Reduced Expression of miR-31 in T Cells of Sepsis Patients Is Associated with Target Gene Up-regulation and Modulates Transcription of $T_{H} 1$ and $T_{H} 2$ Cytokines}

Based on our results suggesting that miR-31 directs $\mathrm{CD} 4^{+} \mathrm{T}$ cells toward a $\mathrm{T}_{\mathrm{H}} 1$ phenotype, it appeared likely that miR-31 also exerts major influence on $\mathrm{T}$ cell responses during sepsis. 

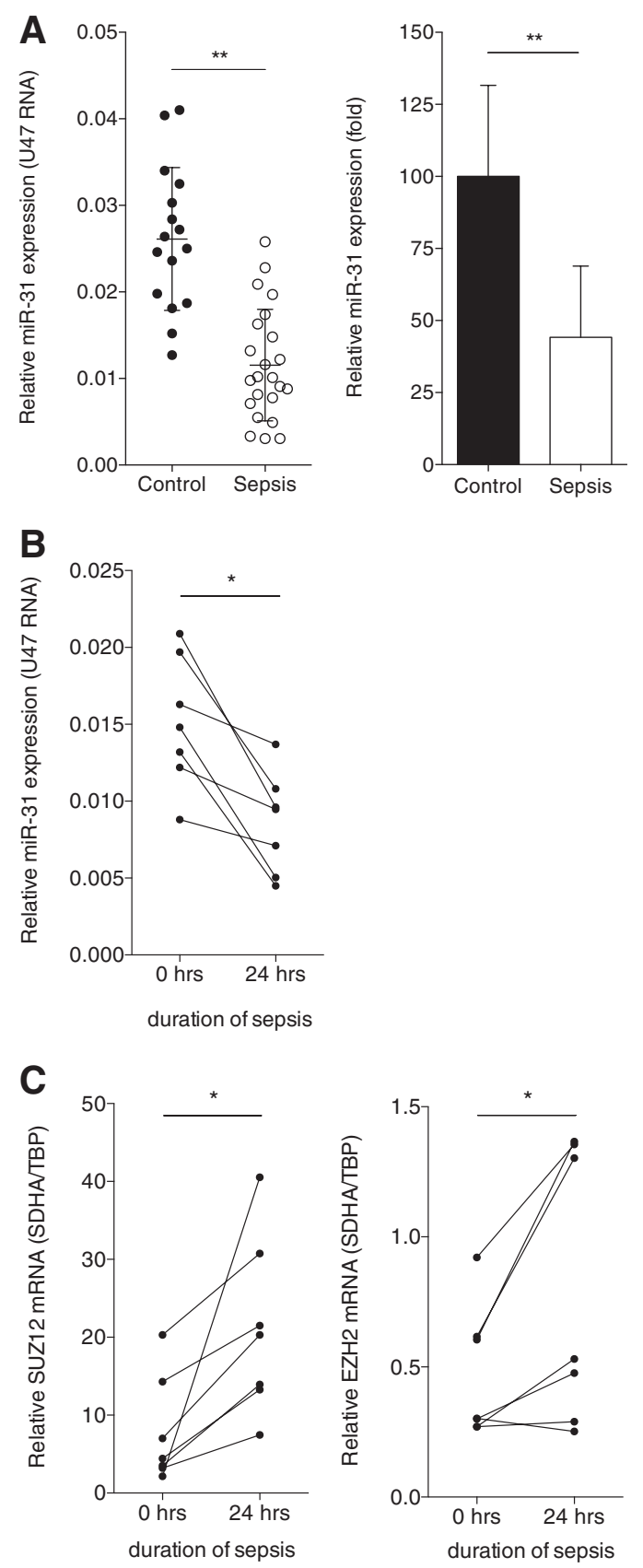

Fig. 4. MicroRNA-31 (miR-31) is down-regulated in T cells of patients with sepsis. (A) Total RNA was extracted from purified $\mathrm{CD}^{+} \mathrm{T}$ cells of sepsis patients ( $n=23$, sepsis) within $48 \mathrm{~h}$ after clinical diagnosis as well as from $\mathrm{CD}^{+} \mathrm{T}$ cells of healthy donors ( $n=16$, control). Relative expression of endogenous miR-31-5p was quantified by quantitative polymerase chain reaction (qPCR) using U47 RNA as normalizing control. Left panel shows scatter dot plot with each symbol representing data from one subject. Horizontal lines delineate means \pm SD. Right panel indicates fold reduction of miR-31 in T cells of the same sepsis patients versus healthy controls. Data are given as means \pm SD. ${ }^{* *} P=0.0001$ in unpaired Student's $t$ test. $(B)$ Blood withdrawal was repeated after a time span of $24 \mathrm{~h}$ in case of seven patients who were diagnosed with early-stage sepsis (symptom onset less than $4 \mathrm{~h}$ ) and miR-31 expression was reanalyzed in $\mathrm{CD}^{+} \mathrm{T}$ cells of these individuals by qPCR.
To address this issue, we quantified miR-31 abundance in $\mathrm{CD}^{+} \mathrm{T}$ cells of sepsis patients enrolled within $48 \mathrm{~h}$ after diagnosis as well as in unstimulated samples of healthy controls (table 1). As depicted in figure 4A, miR-31 expression was reduced by more than $50 \%$ in $\mathrm{CD}^{+} \mathrm{T}$ cells of sepsis patients when compared with healthy controls $(0.44 \pm 0.25$; $P=0.0001$; fig. 4A). Moreover, a weak inverse correlation between miR-31 and the patients' initial Sequential Organ Failure Assessment ${ }^{43}$ scores was found (Supplemental Digital Content 1, table S2, http://links.lww.com/ALN/B247). To explore the kinetics of miR-31 during the initial phase of sepsis, we reassessed its expression $24 \mathrm{~h}$ after the first measurement in patients who had been diagnosed with earlystage sepsis. Of note, when compared with donors with late sepsis (i.e., blood samples were obtained within up to $48 \mathrm{~h}$ after clinical diagnosis), these patients displayed higher miR-31 expression at the time of the first quantification (Supplemental Digital Content 1, fig. S3, http://links.lww. com/ALN/B247). Interestingly, however, miR-31 expression continued to decrease in the respective patients as sepsis persisted ( $P=0.0051$; fig. $4 \mathrm{~B})$. Simultaneously, SUZ12 (left panel) and EZH2 (right panel) transcripts increased (SUZ12: $P=0.022$; EZH2: $P=0.0469$; fig. 4C), which indicates epigenetic regulation of miR-31 in primary human T cells during sepsis.

We reasoned that the miR-31 down-regulation occurring in sepsis might induce alterations in $\mathrm{T}_{\mathrm{H}}$ cytokines contrary to those observed after transfection of miR-31 mimic. To provide experimental proof, we transfected miR-31 hairpin inhibitor (anti-miR-31) into $\mathrm{CD}^{+} \mathrm{T}$ cells of healthy donors. Targeting and transfection efficiency in resting and in stimulated CD4 ${ }^{+} \mathrm{T}$ cells were tested by qPCR (resting: $0.27 \pm 0.13 ; P<0.0001$; anti-C3/CD28: $0.48 \pm 0.24$; $P<0.0001$; fig. 5A, left panel) and flow cytometry, respectively (fig. 5A, see right panel for representative histogram). We then analyzed mRNA levels of the miR-31 target genes NIK, FIH, and SH2D1A following transfection of antimiR-31 or scrambled control. As expected, we detected a significant increase in all three target genes (NIK: $1.73 \pm 0.44$; $P=0.0061$; FIH: $1.32 \pm 0.44, P=0.0465$; SH2D1A: $1.30 \pm 0.11 ; P=0.0024$; fig. 5B). In line with these results, we found significantly increased IL-2 and IL-4 mRNA expression in stimulated $\mathrm{CD}^{+}{ }^{+} \mathrm{T}$ cells (IL-2: $2.23 \pm 0.20$; $P<0.0001$; IL-4: $1.53 \pm 0.32 ; P=0.0113$; fig. $5 \mathrm{C})$, whereas IFN- $\gamma$ levels were reduced $(0.71 \pm 0.25 ; P=0.1136)$.

Fig. 4. (Continued). Zero and $24 \mathrm{~h}$ indicate blood collection and T cell separation at the time of diagnosis as well as $24 \mathrm{~h}$ later. Symbols with connecting lines represent data of individual subjects at the time of diagnosis $(0 \mathrm{~h})$ as well as $24 \mathrm{~h}$ later. ${ }^{*} P=0.0051$ in paired Student's $t$ test. $(C)$ Relative mRNA levels of polycomb group proteins SUZ12 (left panel) and EZH2 (right panel) were quantified in the same samples by qPCR. SUZ12: ${ }^{\star} P=0.022$ in paired Student's $t$ test and EZH2: ${ }^{*} P=0.0469$ in Wilcoxon signed-rank test. SDHA = succinate dehydrogenase subunit $A$; TBP = TATA Box Binding Protein. 

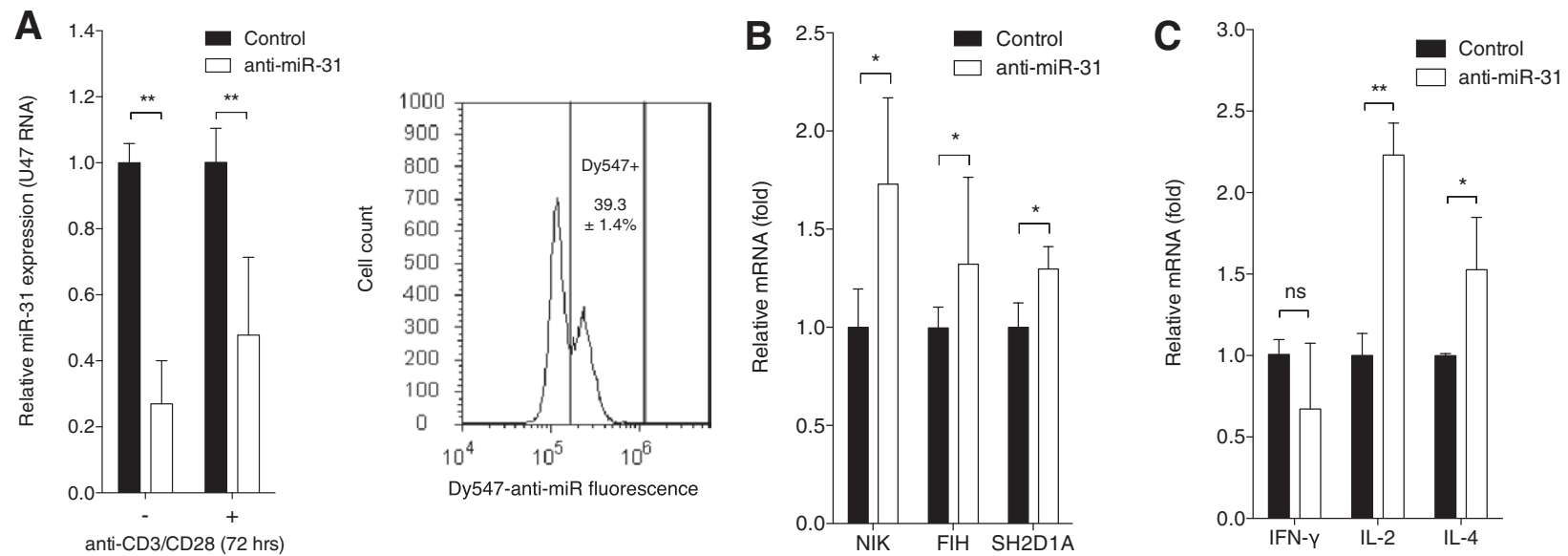

Fig. 5. AntimicroRNA-31 (anti-miR-31) inhibits the previously observed miR-31 effects in purified $\mathrm{T}$ cells of healthy donors. (A) Purified $\mathrm{CD}^{+} \mathrm{T}$ cells of healthy donors $(\mathrm{n}=4)$ were incubated with Accell anti-miR-31-5p (open bars) or a DY547-labeled scrambled control for $72 \mathrm{~h}$ with $(+)$ and without $(-)$ stimulation with anti-CD3/CD28 Dynabeads. Successful transfection was confirmed by quantitative polymerase chain reaction (left panel) as well as by flow cytometry (right panel). Data are means $\pm \mathrm{SD} .{ }^{* \star} P<0.0001$ in paired Student's $t$ test. Histogram is representative of $\mathrm{n}=3$ individual experiments performed in duplicates. $(B, C)$ Relative mRNA levels of the miR-31 target genes nuclear factor-kappa B-inducing kinase (NIK), factor-inhibiting hypoxia-inducible factor-1 $\alpha(\mathrm{FIH})$, and SH2D1A $(B)$ as well as of the $T_{H} 1 / T_{H} 2$ cytokines interferon (IFN)- $\gamma$, interleukin (IL)- 2 , and IL-4 (C) were quantified in CD4+ $4^{+}$cells of healthy donors after $72 \mathrm{~h}$ of incubation with Accell anti-miR-31-5 (open bars) or scrambled control in the absence (in case of target genes) or presence (in case of cytokines) of anti-CD3/CD28 Dynabeads. Data are means \pm SD of $\mathrm{n}=3$ to 4 independent experiments. NIK: ${ }^{*} P=0.0061 ; \mathrm{FIH}:{ }^{*} P=0.0465$; SH2D1A: ${ }^{\star} P=0.0024$; IFN- $\gamma$ : not significant (ns) $P=0.1136$; IL-2: ${ }^{*} P<0.0001$; IL-4: ${ }^{*} P=0.0113$ in paired Student's $t$ test.

Finally, we set out to explore whether these in vitro findings could be transferred to the clinical setting found in sepsis. In fact, we detected increased mRNA levels of NIK $(P=0.9375$; fig. 6A), FIH $(P=0.0184$; fig. 6B), and SH2D1A $(P=0.0466$; fig. $6 \mathrm{C})$ in the majority of early-stage sepsis patients $24 \mathrm{~h}$ after initial quantification at the time of clinical diagnosis. Concordantly, most of these patients exhibited an increase in IL-2 (fig. 6D) and IL-4 (fig. 6E) transcription and a decrease in IFN- $\gamma$ mRNA levels within $24 \mathrm{~h}$ (fig. 6F).

Taken together, our data show that reduction of miR-31 in $T$ cells during the early phase of sepsis modulates $T_{H} 1 /$ $\mathrm{T}_{\mathrm{H}} 2$ cytokine expression toward $\mathrm{T}_{\mathrm{H}} 2$ via up-regulation of the miR-31 target genes NIK, FIH, and SH2D1A.

\section{Discussion}

Research over the past decades mainly focused on the early proinflammatory phase of sepsis. However, recent studies indicate a paradigm shift in the conception of sepsis pathophysiology as they stress that a later and therefore more protracted stage of immunoparalysis plays a detrimental role in the morbidity and mortality of the disease. Among the multiple cellular mechanisms driving sepsis-induced immunosuppression, $\mathrm{T}$ cell pathologies such as cellular dysfunction, apoptotic depletion, and altered patterns of differentiation have been identified as key elements. However, no data on molecular pathways directing these alterations have been reported so far.

In this study, we identify miR-31 as an important novel constituent of the regulatory networks modulating the $\mathrm{T}_{\mathrm{H}} 1 / \mathrm{T}_{\mathrm{H}} 2$ equilibrium in human sepsis: miR-31 safeguards the balance of pro- and antiinflammatory responses of human $\mathrm{CD}^{+} \mathrm{T}$ cells by supporting $\mathrm{T}_{\mathrm{H}} 1$ cytokine transcription and preventing a $\mathrm{T}_{\mathrm{H}} 2$ bias via repression of FIH, NIK, and the newly identified target gene SH2D1A, thereby influencing the networks of HIF-1 $\alpha$, NF-kB, and SLAM receptor signaling. In sepsis, an epigenetically driven down-regulation of miR-31 expression promotes a $\mathrm{CD}^{+} \mathrm{T}$ cell shift toward a $\mathrm{T}_{\mathrm{H}} 2$ phenotype via up-regulation of these target genes, thus facilitating the transition from a hyperinflammatory to an immunoparalytic state.

In neoplastic development and tumor metastasis, miR-31 was previously shown to be an endogenous negative regulator of $\mathrm{FIH}^{23}$ and NIK, ${ }^{24}$ thereby activating the HIF- $1 \alpha$ and restricting the noncanonical NF- $\kappa$ B pathway. Since both signaling pathways are highly interrelated with inflammatory processes, these studies have led us to assume a role for miR31 as a regulator of $\mathrm{T}$ cell functions.

In fact, we found that in vitro activated T cells of healthy donors exhibit significantly diminished miR-31 levels when compared with unstimulated controls and that persistent stimulation of the TCR provoked a steady decline in miR-31 abundance, suggesting that expression of miR31 is closely related to the $\mathrm{T}$ cell activation status. In vitro overexpression of miR-31 in stimulated human $\mathrm{CD}^{+} \mathrm{T}$ cells induced a proinflammatory phenotype with increased levels of IFN- $\gamma$ mRNA and reduced transcription of IL-2 and IL-4. These cytokines play prominent roles in the complex networks of immune responses during sepsis. Whereas proinflammatory IFN $-\gamma$ has been shown to promote $T_{H} 1$ 

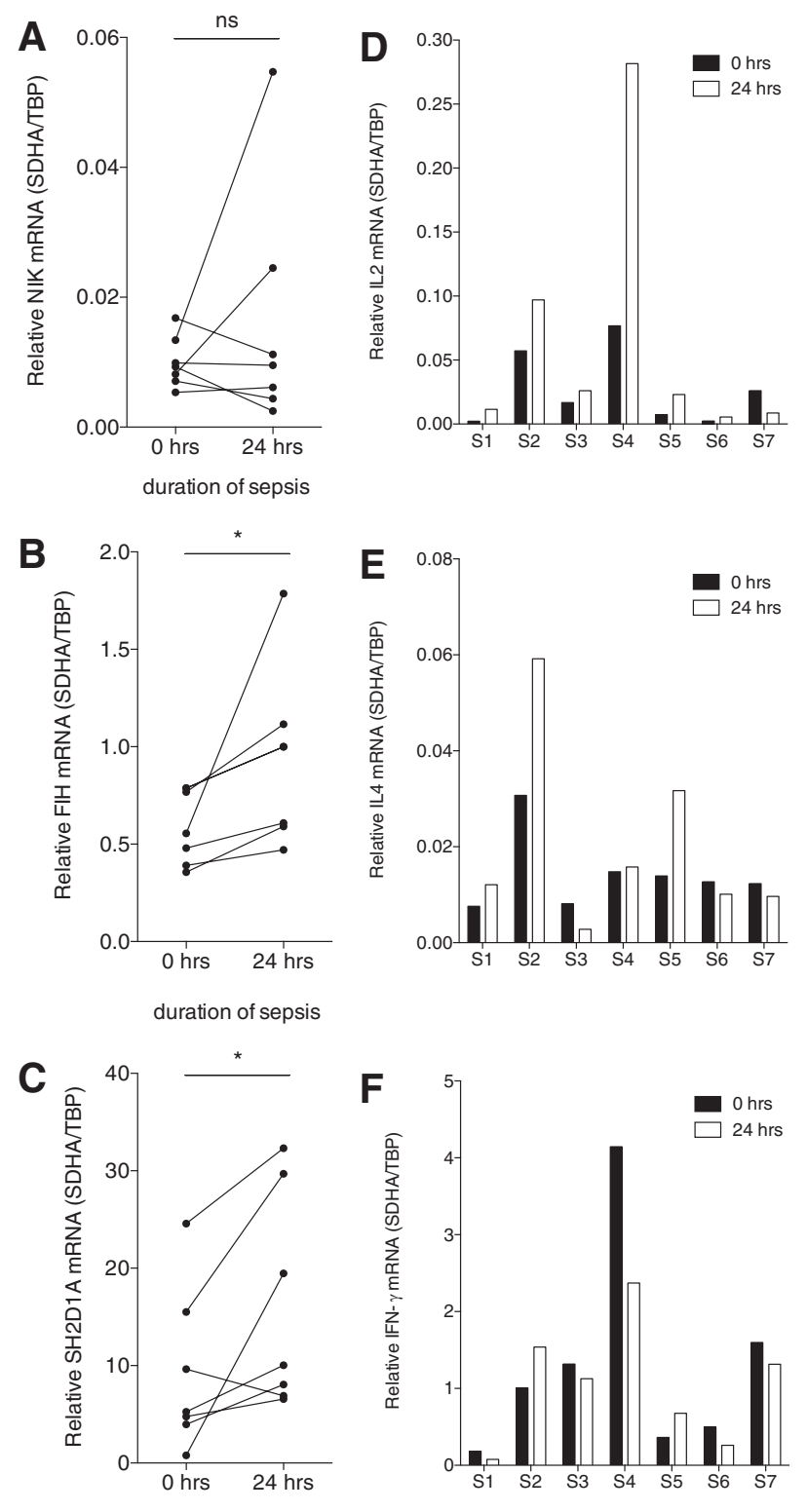

Fig. 6. Reduced expression of microRNA-31 (miR-31) in $T$ cells of sepsis patients is associated with target gene up-regulation and modulates transcription of $T_{H} 1$ and $T_{H} 2$ cytokines. $(A-F)$ Relative mRNA expression of the miR-31 target genes nuclear factor-kappa B-inducing kinase (NIK) $(A)$, factor-inhibiting hypoxia-inducible factor-1 $\alpha(\mathrm{FIH})(B)$, and $\mathrm{SH} 2 \mathrm{D} 1 \mathrm{~A}(C)$ as well as transcription of $\mathrm{T}_{\mathrm{H}} 1$ and $\mathrm{T}_{\mathrm{H}} 2 \mathrm{cy}-$ tokines interleukin (IL)-2 (D), IL-4 (E), and interferon (IFN)- $\gamma$ $(F)$ were analyzed in the $\mathrm{CD}^{+} \mathrm{T}$ cell samples of those seven patients (S1-S7) diagnosed with early sepsis at the time of diagnosis $(0 \mathrm{~h})$ and $24 \mathrm{~h}$ later $(24 \mathrm{~h})$. ( $A-C)$ Symbols with connecting lines represent data of individual subjects at 0 and $24 \mathrm{~h}$. Not significant (ns) in Wilcoxon signed-rank test (NIK, $P=0.9375)$; *in paired Student'st test (FIH, $P=0.0184$; SH2D1A, $P=0.0466)$. ( $D-F)$ Raw data of relative cytokine mRNA expression for each subject diagnosed with early sepsis (S1-S7) at the time of diagnosis (0h, black bars) as well as $24 \mathrm{~h}$ later $(24 \mathrm{~h}$, open bars). SDHA = succinate dehydrogenase subunit A; TBP = TATA Box Binding Protein. differentiation to activate immune effector cell functions and to mediate pathogen clearance during the initial hyperinflammatory septic response, ${ }^{44-46}$ antiinflammatory IL-4 induces $\mathrm{T}_{\mathrm{H}} 2$ polarization as well as suppression of macrophage and neutrophil activities in the immunosuppressive stage of sepsis. ${ }^{47,48}$ IL-2, however, plays an essential role in both pro- and antiinflammatory reactions during inflammatory disorders, promoting lymphocyte proliferation ${ }^{49}$ as well as limiting excessive immune responses in autoimmune diseases such as myasthenia gravis ${ }^{50}$ and diabetes mellitus. ${ }^{51}$

When investigating whether the interaction of miR-31 with NIK and FIH may be responsible for the observed effects on the cytokine profiles of $\mathrm{CD}^{+} \mathrm{T}$ cells, we found the functional miR-31-NIK and miR-31-FIH relationship to be maintained in human T cells. Surprisingly, only the miR-31 effects on IL-2 and IL- 4 could be attributed to targeting of these two target genes. In line with results of previously published studies, ${ }^{52-54}$ knockdown of NIK induced a profound reduction in IL-2 transcription. In hypoxia, a hallmark of inflammation, ${ }^{55}$ the observed effect on IL-2 expression, is additionally enforced by miR-31-mediated repression of FIH. Moreover, knockdown of FIH resulted in substantial reduction of IL-4 mRNA levels, which is in accordance with previous findings reporting that activated HIF-1 $\alpha$-deficient murine splenocytes produce more IL-4. ${ }^{26}$ Unexpectedly, neither NIK nor FIH targeting could account for the miR-31-induced up-regulation of IFN- $\gamma$.

In silico analysis predicted two miR-31-binding sites with favorable scores suggesting SAP to be the missing link between miR-31 and IFN- $\gamma$ regulation. SAP is the gene product of $\mathrm{SH} 2 \mathrm{D} 1 \mathrm{~A}$ and is known to activate many signaling pathways downstream of the SLAM family of immune cell receptors, CD150 (SLAM), CD229 (Ly9), CD244 (2B4), CD84 (SLAMF5), NK-T-B antigen (SLAMF6), and CD319 (CD2like receptor activating cytotoxic cell). ${ }^{56,57}$ Engagement of SLAM receptors influences cytokine expression, for example, IFN- $\gamma$ production, ${ }^{56}$ and results in initiation of $\mathrm{T}$ cell-mediated signals such as protein kinase C- $\theta$ and NF- $\kappa$ B activation. ${ }^{41}$ Moreover, mutations in SAP have been demonstrated to lead to enhanced IFN- $\gamma$ levels upon T cell stimulation. ${ }^{41,42}$ In the present study, we provide several lines of evidence that SH2D1A is a bona fide target of miR-31 and that the effect of miR-31 on IFN- $\gamma$ expression in primary $\mathrm{CD}^{+} \mathrm{T}$ cells is mediated via miR-31-SH2D1A regulation. First, luciferase reporter gene assays with wild-type and mutant vectors demonstrated that miR-31 negatively regulates the SH2D1A 3'-UTR. In addition, exogenous overexpression of miR-31 in primary human $\mathrm{T}$ cells led to substantially reduced levels of SAP expression. Second, T cell activation substantially increased SAP abundance in T cells of healthy donors, displaying expression kinetics resembling those of the miR-31 targets FIH and NIK, and third, siRNA targeting of SH2D1A resulted in enhanced IFN- $\gamma$ transcription. Taken together, these data establish an miR-31/NIK/FIH/SAP nexus that modulates human $\mathrm{CD}^{+} \mathrm{T}$ cell functions via the HIF-1 $\alpha$, $\mathrm{NF}-\kappa \mathrm{B}$, and SLAM receptor signaling pathways. 
When examining $\mathrm{T}$ cells of sepsis patients enrolled up to $48 \mathrm{~h}$ after clinical diagnosis, we found that endogenous expression of miR-31 was significantly reduced when compared with healthy controls. This is consistent with previous studies reporting diminished levels of miR-31 in T cells of patients with systemic lupus erythematosus ${ }^{58}$ as well as in peripheral blood mononuclear cells of patients diagnosed with influenza A. ${ }^{59}$ After lowering the level of miR-31 in $\mathrm{CD}^{+} \mathrm{T}$ cells of healthy donors by use of a miR-31 hairpin inhibitor to mimic septic conditions, increased transcription of NIK, FIH, and SH2D1A could be detected, which was associated with enhanced IL- 2 and IL- 4 as well as decreased IFN- $\gamma$ levels. This underlines the validity of our analysis and provides further insight into the impact of mir-31 in sepsis. Noteworthy, in patients diagnosed with early-stage sepsis, a further substantial decrease in miR-31 abundance occurred within $24 \mathrm{~h}$ after the initial quantification. These decreasing kinetics were accompanied by an increase in NIK, FIH, and SH2D1A gene expression. Moreover, the majority of earlystage sepsis patients displayed increased IL-2 and IL- 4 as well as reduced IFN- $\gamma$ mRNA expression, potentially favoring an antiinflammatory $\mathrm{T}_{\mathrm{H}} 2$ bias such as typically occurs during the immunosuppressive phase of the disease.

Our findings regarding miR-31-mediated cytokine kinetics in T cells of early-stage sepsis patients are in accordance with a previous study showing that the early phase of sepsis is characterized by a combination of $T$ cell apoptosis and simultaneous $\mathrm{T}$ cell proliferation, ${ }^{60}$ a process that necessarily depends on IL-2 secretion. Moreover, increased levels of both IL-4 and other antiinflammatory cytokines have been repeatedly described during sepsis, ${ }^{61,62}$ potentially driving the development and persistence of immunosuppression. ${ }^{47}$ In this context, Boomer $e t$ al. ${ }^{7}$ have demonstrated that $T$ cells of sepsis patients produce significantly less IFN- $\gamma$ upon TCR stimulation, which has been associated with both restricted $\mathrm{T}_{\mathrm{H}} 1$ differentiation ${ }^{46}$ and reduced macrophage activation. ${ }^{44}$ Thus, our results point out a strong impact of miR-31 kinetics in endogenously activated $T$ cells of sepsis patients.

As a potentially underlying mechanism leading to repression of miR-31 in activated $\mathrm{T}$ cells, we identified markedly up-regulated gene transcription of the polycomb group (PcG) proteins EZH2 and SUZ12. Being core components of the polycomb repressive complex 2, EZH2 and SUZ12 are involved in numerous pathophysiological processes, promoting transcriptional repression and influencing cell fate regulation via histone methylation. ${ }^{63-65}$ MiR-31 has been shown to be epigenetically regulated by the PcG proteins EZH2 and SUZ12 both in adult $\mathrm{T}$ cell leukemia ${ }^{24}$ and in melanoma cells, ${ }^{38}$ generally resulting in apoptosis resistance and tumor progression. Therefore, recent focus has been laid on targeting PcG proteins as a novel treatment option in cancer. ${ }^{66}$ In the current study, we now show that PcG-mediated negative regulation of miR-31 might also influence critical inflammatory responses in sepsis.
Mortality in sepsis still ranges between 30 and 50\%. ${ }^{1,2}$ Failure of former therapeutic approaches has led to a reevaluation of conceptions regarding sepsis pathophysiology, which laid new focus on the immunosuppressive phase of the disease. Due to the diversity of mechanisms influencing adaptive immune responses during sepsis, identification of hubs controlling these inflammatory processes is rather challenging. Taken together, we here provide novel evidence of miR31 as an emerging key posttranscriptional regulator of $\mathrm{T}_{\mathrm{H}} 2$ skewing in human sepsis, which contributes to sepsis-associated immunosuppression. Reduced expression of miR-31 in $\mathrm{T}$ cells of sepsis patients induces up-regulation of the miR-31 targets NIK, FIH, and SH2D1A, thus favoring an immunosuppressive $\mathrm{T}_{\mathrm{H}} 2$ bias of $\mathrm{T}$ cell differentiation. Our data suggest clinical relevance of these functional relationships in sepsis patients and point out miR-31 expression in $\mathrm{T}$ cells to be a potential biomarker to monitor the development and prevalence of sepsis-associated immunodeficiency. The implications of these early findings will now have to be tested in a larger-scale study with a particular focus on the role of miR-31 in septic CD $4^{+} \mathrm{T}$ cells to confirm the mechanistic associations proposed here.

\section{Acknowledgments}

This study was supported by the Department of Anesthesiology, Ludwig Maximilian University Munich, Munich, Germany, and by the Charles Evans Foundation, New York, New York.

\section{Competing Interests}

The authors declare no competing interests.

\section{Correspondence}

Address correspondence to Dr. Kreth: Department of Anesthesiology, University of Munich (LMU), Marchioninistrasse 15, 81377 Munich, Germany. simone.kreth@med.uni-muenchen.de. Information on purchasing reprints may be found at www. anesthesiology.org or on the masthead page at the beginning of this issue. Anesthesiology's articles are made freely accessible to all readers, for personal use only, 6 months from the cover date of the issue.

\section{References}

1. Levy MM, Artigas A, Phillips GS, Rhodes A, Beale R, Osborn $\mathrm{T}$, Vincent JL, Townsend $\mathrm{S}$, Lemeshow S, Dellinger RP: Outcomes of the Surviving Sepsis Campaign in intensive care units in the USA and Europe: A prospective cohort study. Lancet Infect Dis 2012; 12:919-24

2. Gaieski DF, Edwards JM, Kallan MJ, Carr BG: Benchmarking the incidence and mortality of severe sepsis in the United States. Crit Care Med 2013; 41:1167-74

3. Hotchkiss RS, Monneret G, Payen D: Sepsis-induced immunosuppression: From cellular dysfunctions to immunotherapy. Nat Rev Immunol 2013; 13:862-74

4. Venet F, Chung CS, Monneret G, Huang X, Horner B, Garber M, Ayala A: Regulatory $\mathrm{T}$ cell populations in sepsis and trauma. J Leukoc Biol 2008; 83:523-35

5. Cuenca AG, Delano MJ, Kelly-Scumpia KM, Moreno C, Scumpia PO, Laface DM, Heyworth PG, Efron PA, Moldawer 
LL: A paradoxical role for myeloid-derived suppressor cells in sepsis and trauma. Mol Med 2011; 17:281-92

6. Brudecki L, Ferguson DA, McCall CE, El Gazzar M: Myeloidderived suppressor cells evolve during sepsis and can enhance or attenuate the systemic inflammatory response. Infect Immun 2012; 80:2026-34

7. Boomer JS, Shuherk-Shaffer J, Hotchkiss RS, Green JM: A prospective analysis of lymphocyte phenotype and function over the course of acute sepsis. Crit Care 2012; 16:R112

8. Boomer JS, To $\mathrm{K}$, Chang $\mathrm{KC}$, Takasu $\mathrm{O}$, Osborne $\mathrm{DF}$, Walton AH, Bricker TL, Jarman SD II, Kreisel D, Krupnick AS, Srivastava A, Swanson PE, Green JM, Hotchkiss RS Immunosuppression in patients who die of sepsis and multiple organ failure. JAMA 2011; 306:2594-605

9. Hotchkiss RS, Swanson PE, Freeman BD, Tinsley KW, Cobb JP, Matuschak GM, Buchman TG, Karl IE: Apoptotic cell death in patients with sepsis, shock, and multiple organ dysfunction. Crit Care Med 1999; 27:1230-51

10. Le Tulzo Y, Pangault C, Gacouin A, Guilloux V, Tribut O, Amiot L, Tattevin P, Thomas R, Fauchet R, Drénou B: Early circulating lymphocyte apoptosis in human septic shock is associated with poor outcome. Shock 2002; 18:487-94

11. Chang K, Svabek C, Vazquez-Guillamet C, Sato B, Rasche D, Wilson S, Robbins P, Ulbrandt N, Suzich J, Green J, Patera AC, Blair W, Krishnan S, Hotchkiss R: Targeting the programmed cell death 1: Programmed cell death ligand 1 pathway reverses $\mathrm{T}$ cell exhaustion in patients with sepsis. Crit Care 2014; 18:R3

12. Guignant C, Lepape A, Huang X, Kherouf H, Denis L, Poitevin F, Malcus C, Chéron A, Allaouchiche B, Gueyffier F, Ayala A, Monneret G, Venet F: Programmed death-1 levels correlate with increased mortality, nosocomial infection and immune dysfunctions in septic shock patients. Crit Care 2011; 15:R99

13. Shubin NJ, Chung CS, Heffernan DS, Irwin LR, Monaghan SF, Ayala A: BTLA expression contributes to septic morbidity and mortality by inducing innate inflammatory cell dysfunction. J Leukoc Biol 2012; 92:593-603

14. Shubin NJ, Monaghan SF, Heffernan DS, Chung CS, Ayala A $\mathrm{B}$ and $\mathrm{T}$ lymphocyte attenuator expression on CD4+ T-cells associates with sepsis and subsequent infections in ICU patients. Crit Care 2013; 17:R276

15. White M, Mahon V, Grealy R, Doherty DG, Stordeur P, Kelleher DP, McManus R, Ryan T: Post-operative infection and sepsis in humans is associated with deficient gene expression of $\gamma_{c}$ cytokines and their apoptosis mediators. Crit Care 2011; 15:R158

16. Roth G, Moser B, Krenn C, Brunner M, Haisjackl M, Almer G, Gerlitz S, Wolner E, Boltz-Nitulescu G, Ankersmit HJ: Susceptibility to programmed cell death in T-lymphocytes from septic patients: A mechanism for lymphopenia and Th2 predominance. Biochem Biophys Res Commun 2003; 308:840-6

17. Bartel DP: MicroRNAs: Target recognition and regulatory functions. Cell 2009; 136:215-33

18. Montano M: MicroRNAs: miRRORS of health and disease. Transl Res 2011; 157:157-62

19. O'Connell RM, Rao DS, Baltimore D: microRNA regulation of inflammatory responses. Annu Rev Immunol 2012 30:295-312

20. Schetter AJ, Heegaard NH, Harris CC: Inflammation and cancer: Interweaving microRNA, free radical, cytokine and p53 pathways. Carcinogenesis 2010; 31:37-49

21. Creighton CJ, Fountain MD, Yu Z, Nagaraja AK, Zhu H, Khan M, Olokpa E, Zariff A, Gunaratne PH, Matzuk MM, Anderson ML: Molecular profiling uncovers a p53-associated role for microRNA-31 in inhibiting the proliferation of serous ovarian carcinomas and other cancers. Cancer Res 2010; 70:1906-15

22. Valastyan S, Reinhardt F, Benaich N, Calogrias D, Szász AM, Wang ZC, Brock JE, Richardson AL, Weinberg RA: A pleiotropically acting microRNA, miR-31, inhibits breast cancer metastasis. Cell 2009; 137:1032-46

23. Liu CJ, Tsai MM, Hung PS, Kao SY, Liu TY, Wu KJ, Chiou SH, Lin SC, Chang KW: miR-31 ablates expression of the HIF regulatory factor FIH to activate the HIF pathway in head and neck carcinoma. Cancer Res 2010; 70:1635-44

24. Yamagishi M, Nakano K, Miyake A, Yamochi T, Kagami Y, Tsutsumi A, Matsuda Y, Sato-Otsubo A, Muto S, Utsunomiya $A$, Yamaguchi $K$, Uchimaru $K$, Ogawa $S$, Watanabe $T$ : Polycomb-mediated loss of miR-31 activates NIK-dependent NF-KB pathway in adult $\mathrm{T}$ cell leukemia and other cancers. Cancer Cell 2012; 21:121-35

25. Thiel M, Caldwell CC, Kreth S, Kuboki S, Chen P, Smith P, Ohta A, Lentsch AB, Lukashev D, Sitkovsky MV: Targeted deletion of HIF-1alpha gene in T cells prevents their inhibition in hypoxic inflamed tissues and improves septic mice survival. PLoS One 2007; 2:e853

26. Lukashev D, Klebanov B, Kojima H, Grinberg A, Ohta A, Berenfeld L, Wenger RH, Ohta A, Sitkovsky M: Cutting edge: Hypoxia-inducible factor 1alpha and its activation-inducible short isoform I.1 negatively regulate functions of CD4+ and CD8+ T lymphocytes. J Immunol 2006; 177:4962-5

27. Eltzschig HK, Carmeliet P: Hypoxia and inflammation. N Engl J Med 2011; 364:656-65

28. Taylor CT: Interdependent roles for hypoxia inducible factor and nuclear factor-kappaB in hypoxic inflammation. J Physiol 2008; 586(Pt 17):4055-9

29. Gerondakis S, Fulford TS, Messina NL, Grumont RJ: NF- $\mathrm{kB}$ control of T cell development. Nat Immunol 2014; 15:15-25

30. Levy MM, Fink MP, Marshall JC, Abraham E, Angus D, Cook D, Cohen J, Opal SM, Vincent JL, Ramsay G; SCCM/ ESICM/ACCP/ATS/SIS: 2001 SCCM/ESICM/ACCP/ATS/SIS International Sepsis Definitions Conference. Crit Care Med $2003 ; 31: 1250-6$

31. Ledderose C, Möhnle P, Limbeck E, Schütz S, Weis F, Rink J, Briegel J, Kreth S: Corticosteroid resistance in sepsis is influenced by microRNA-124-induced downregulation of glucocorticoid receptor- $\alpha$. Crit Care Med 2012; 40:2745-53

32. Möhnle P, Schütz SV, van der Heide V, Hübner M, Luchting B, Sedlbauer J, Limbeck E, Hinske LC, Briegel J, Kreth S: MicroRNA-146a controls Th1-cell differentiation of human CD4+ T lymphocytes by targeting PRKCE. Eur J Immunol 2015; 45:260-72

33. Lewis BP, Burge CB, Bartel DP: Conserved seed pairing, often flanked by adenosines, indicates that thousands of human genes are microRNA targets. Cell 2005; 120:15-20

34. Ledderose C, Heyn J, Limbeck E, Kreth S: Selection of reliable reference genes for quantitative real-time PCR in human T cells and neutrophils. BMC Res Notes 2011; 4:427

35. Betel D, Koppal A, Agius P, Sander C, Leslie C: Comprehensive modeling of microRNA targets predicts functional non-conserved and non-canonical sites. Genome Biol 2010; 11:R90

36. John B, Enright AJ, Aravin A, Tuschl T, Sander C, Marks DS: Human MicroRNA targets. PLoS Biol 2004; 2:e363

37. Kertesz M, Iovino N, Unnerstall U, Gaul U, Segal E: The role of site accessibility in microRNA target recognition. Nat Genet 2007; 39:1278-84

38. Asangani IA, Harms PW, Dodson L, Pandhi M, Kunju LP, Maher CA, Fullen DR, Johnson TM, Giordano TJ, Palanisamy N, Chinnaiyan AM: Genetic and epigenetic loss of microRNA-31 leads to feed-forward expression of EZH2 in melanoma. Oncotarget 2012; 3:1011-25

39. McNamee EN, Korns Johnson D, Homann D, Clambey ET: Hypoxia and hypoxia-inducible factors as regulators of T cell development, differentiation, and function. Immunol Res 2013; 55:58-70

40. Caldwell CC, Kojima H, Lukashev D, Armstrong J, Farber M, Apasov SG, Sitkovsky MV: Differential effects of physiologically relevant hypoxic conditions on $\mathrm{T}$ lymphocyte 
development and effector functions. J Immunol 2001; 167:6140-9

41. Cannons JL, Yu LJ, Hill B, Mijares LA, Dombroski D, Nichols KE, Antonellis A, Koretzky GA, Gardner K, Schwartzberg PL: SAP regulates $\mathrm{T}(\mathrm{H}) 2$ differentiation and $\mathrm{PKC}$-theta-mediated activation of NF-kappaB1. Immunity 2004; 21:693-706

42. Czar MJ, Kersh EN, Mijares LA, Lanier G, Lewis J, Yap G, Chen A, Sher A, Duckett CS, Ahmed R, Schwartzberg PL: Altered lymphocyte responses and cytokine production in mice deficient in the X-linked lymphoproliferative disease gene SH2D1A/DSHP/SAP. Proc Natl Acad Sci U S A 2001; 98:7449-54

43. Ferreira FL, Bota DP, Bross A, Mélot C, Vincent JL: Serial evaluation of the SOFA score to predict outcome in critically ill patients. JAMA 2001; 286:1754-8

44. Held TK, Weihua X, Yuan L, Kalvakolanu DV, Cross AS Gamma interferon augments macrophage activation by lipopolysaccharide by two distinct mechanisms, at the signal transduction level and via an autocrine mechanism involving tumor necrosis factor alpha and interleukin-1. Infect Immun 1999; 67:206-12

45. Murphey ED, Lin CY, McGuire RW, Toliver-Kinsky T, Herndon DN, Sherwood ER: Diminished bacterial clearance is associated with decreased IL-12 and interferon-gamma production but a sustained proinflammatory response in a murine model of postseptic immunosuppression. Shock 2004; 21:415-25

46. Smeltz RB, Chen J, Ehrhardt R, Shevach EM: Role of IFNgamma in Th1 differentiation: IFN-gamma regulates IL-18R alpha expression by preventing the negative effects of IL- 4 and by inducing/maintaining IL-12 receptor beta 2 expression. J Immunol 2002; 168:6165-72

47. Song GY, Chung CS, Chaudry IH, Ayala A: IL-4-induced activation of the Stat6 pathway contributes to the suppression of cell-mediated immunity and death in sepsis. Surgery 2000 128:133-8

48. Bogdan C, Vodovotz Y, Paik J, Xie QW, Nathan C: Mechanism of suppression of nitric oxide synthase expression by interleukin- 4 in primary mouse macrophages. J Leukoc Biol 1994; 55:227-33

49. Williams MA, Tyznik AJ, Bevan MJ: Interleukin-2 signals during priming are required for secondary expansion of CD8+ memory T cells. Nature 2006; 441:890-3

50. Liu R, Zhou Q, La Cava A, Campagnolo DI, Van Kaer L, Shi FD: Expansion of regulatory T cells via IL-2/anti-IL-2 mAb complexes suppresses experimental myasthenia. Eur J Immunol 2010; 40:1577-89

51. Tang Q, Adams JY, Penaranda C, Melli K, Piaggio E, Sgouroudis E, Piccirillo CA, Salomon BL, Bluestone JA: Central role of defective interleukin-2 production in the triggering of islet autoimmune destruction. Immunity 2008; 28:687-97

52. Sánchez-Valdepeñas $C$, Martín AG, Ramakrishnan $P$, Wallach $\mathrm{D}$, Fresno M: NF-kappaB-inducing kinase is involved in the activation of the $\mathrm{CD} 28$ responsive element through phosphorylation of c-Rel and regulation of its transactivating activity. J Immunol 2006; 176:4666-74

53. Matsumoto $M$, Yamada T, Yoshinaga SK, Boone T, Horan T, Fujita S, Li Y, Mitani T: Essential role of NF-kappa B-inducing kinase in $\mathrm{T}$ cell activation through the TCR/CD3 pathway. J Immunol 2002; 169:1151-8

54. Yamada T, Mitani T, Yorita K, Uchida D, Matsushima A Iwamasa K, Fujita S, Matsumoto M: Abnormal immune function of hemopoietic cells from alymphoplasia (aly) mice, a natural strain with mutant NF-kappa B-inducing kinase. J Immunol 2000; 165:804-12

55. Bartels K, Grenz A, Eltzschig HK: Hypoxia and inflammation are two sides of the same coin. Proc Natl Acad Sci U S A 2013; 110:18351-2

56. Schwartzberg PL, Mueller KL, Qi H, Cannons JL: SLAM receptors and SAP influence lymphocyte interactions, development and function. Nat Rev Immunol 2009; 9:39-46

57. Veillette A: SLAM-family receptors: Immune regulators with or without SAP-family adaptors. Cold Spring Harb Perspect Biol 2010; 2:a002469

58. Fan W, Liang D, Tang Y, Qu B, Cui H, Luo X, Huang X, Chen S, Higgs BW, Jallal B, Yao Y, Harley JB, Shen N: Identification of microRNA-31 as a novel regulator contributing to impaired interleukin-2 production in T cells from patients with systemic lupus erythematosus. Arthritis Rheum 2012; 64:3715-25

59. Song H, Wang Q, Guo Y, Liu S, Song R, Gao X, Dai L, Li B, Zhang D, Cheng J: Microarray analysis of microRNA expression in peripheral blood mononuclear cells of critically ill patients with influenza A (H1N1). BMC Infect Dis 2013; $13: 257$

60. Roger PM, Hyvernat H, Ticchioni M, Kumar G, Dellamonica J, Bernardin G: The early phase of human sepsis is characterized by a combination of apoptosis and proliferation of $T$ cells. J Crit Care 2012; 27:384-93

61. DiPiro JT, Howdieshell TR, Goddard JK, Callaway DB, Hamilton RG, Mansberger AR Jr: Association of interleukin-4 plasma levels with traumatic injury and clinical course. Arch Surg 1995; 130:1159-62; discussion 1162-3

62. Wu HP, Wu CL, Chen CK, Chung K, Tseng JC, Liu YC, Chuang DY: The interleukin- 4 expression in patients with severe sepsis. J Crit Care 2008; 23:519-24

63. Cifuentes-Rojas C, Hernandez AJ, Sarma K, Lee JT: Regulatory interactions between RNA and polycomb repressive complex 2. Mol Cell 2014; 55:171-85

64. Margueron R, Reinberg D: The Polycomb complex PRC2 and its mark in life. Nature 2011; 469:343-9

65. Kirmizis A, Bartley SM, Kuzmichev A, Margueron R, Reinberg D, Green R, Farnham PJ: Silencing of human polycomb target genes is associated with methylation of histone H3 Lys 27. Genes Dev 2004; 18:1592-605

66. Kondo Y: Targeting histone methyltransferase EZH2 as cancer treatment. J Biochem 2014; 156:249-57 